\title{
Development of an integrated network for waste-to-energy and central utility systems considering air pollutant emissions pinch analysis
}

\author{
Hwangbo, Soonho; Sin, Gürkan; Rhee, Gahee; Yoo, Chang Kyoo
}

Published in:

Journal of cleaner production

Link to article, DOI:

10.1016/j.jclepro.2019.119746

Publication date:

2020

Document Version

Peer reviewed version

Link back to DTU Orbit

Citation $(A P A)$ :

Hwangbo, S., Sin, G., Rhee, G., \& Yoo, C. K. (2020). Development of an integrated network for waste-to-energy and central utility systems considering air pollutant emissions pinch analysis. Journal of cleaner production, 252, [119746]. https://doi.org/10.1016/j.jclepro.2019.119746

\section{General rights}

Copyright and moral rights for the publications made accessible in the public portal are retained by the authors and/or other copyright owners and it is a condition of accessing publications that users recognise and abide by the legal requirements associated with these rights.

- Users may download and print one copy of any publication from the public portal for the purpose of private study or research.

- You may not further distribute the material or use it for any profit-making activity or commercial gain

- You may freely distribute the URL identifying the publication in the public portal 


\section{Development of integrated utility and waste-to-enery network considering hybrid global warming potential pinch analysis}

Soonho Hwnagbo ${ }^{a}$, Gürkan Sin ${ }^{a}$ and ChangKyoo Yoo ${ }^{b, *}$

a Process and Systems Engineering Center (PROSYS), Department of Chemical and Biochemical Engineering, Technical University of Denmark, Building 229, DK-2800, Kgs. Lyngby, Denmark.

${ }^{\mathrm{b}}$ Department of Environmetnal Science and Engineering, Center for Environmental Sudies, Kyung Hee University, Yongin-Si, 446-701, Korea

*Corresponding author: Tel. +82-31-201-3824; Fax. +82-31-202-8854

E-mail address: ckyoo@khu.ac.kr 


\begin{abstract}
This study aims to integrate utility supply networks in a petrochemical industrial complex and adjoining waste-to-energy networks to accomplish an eco-friendly energy management system. The waste-to-energy network studied in this contribution included the following main systems: (1) wastewater treatment plants for biogas production, (2) biogas upgrading process for biomethane generation, and (3) molten carbonate fuel cell systems together with a Rankine cycle to harness green electricity. Waste streams in the proposed model consist of wastewater in waste-to-energy network and wasted steam from utlity supply networks. Derived green electricity is utilized to satisfy energy demands in the utility supply networks. To design and analyze as optimal waste-to-energy network system, a mixed integer nonlinear programming problem is formulated where each of the subsystem is simulated by developing an appropriate process model. The optimization problem is solved for optimization of the utility supply network and sustainability of the solutions with respect to global warming potential is studied. A case study of Yeosu petrochemical instustrial complex in South Korea has been applied for the developed model. The total economic costs of the optimized utility supply network based on the integrated utility and waste-to-energy network are reduced by approximately $15 \%$ compared to the exisiting utility supply network. Furthermore, the results from the hybrid global warming potential pinch analysis indicate that the total quantites of global warming potential ( emitted from the integrated utility and waste-to-energy network decrease about 35\%. Consequently, the feasibility of combining two networks has been demonstrated from environmental and economic points of view.
\end{abstract}

Keywords: Waste-to-enery network; Utility supply network; Hybrid global warming potential pinch analysis; Optimization; Petrochemical industry.

Abbreviations: WTE, waste-to-energy; USN, utility supply network, IUWTE, integrated utility and wasteto-energy, GWP, global warming potential; EIP, eco-industrial park; WWTP, wastewater treatment plant; $\mathrm{CO}_{2}$, carbon dioxide; $\mathrm{CO}$, carbon monoxide; MEA, monoethanoamine; MCFC, molten carbonate fuel cell; BSM2, benchmark simulation model no.2; SMR, steam methane reforming; 


\section{Introduction}

Many countries and institutions have been insistently researching and investing on the energy management for the purose of evolving an environmentally benign energy system. The modification and qualification of the exisiting process systems or the integration of a variety of energy/utility supply networks make it possible to reduce global warming potential (GWP) under the systematic energy management. Considerations of waste-to-energy (WTE) and eco-industiral park (EIP) can potentially generate sophisticated strategies for visualizing an opening of the clean energy economy

WTE, which is a form of energy recovery, is able to generate electricity and/or heat from the diverse treatment processes of wastes. Many studies based on WTE approach have been researched to identify environmentally benign processes and a promising waste management system with respect to energy and economics. Sustainable waste and environmental management based on WTE plants treating municipal solid waste has been suggested to reach the aims of protection of human beings and environment and resource conservation [1]. Energy, economic, and environmental analysis of WTE scenarios have been applied for Malaysia, which is greatly depedent on landfills for municipal solid waste management, to develop a better waste management strategy [2]. WTE supply chain for circular economy system has been resesarched to propose a number of key task-forces for executing feasible strategis and portfolio for WTE technoloiges have been addressed [3]. And, the biological process of biohydrogen production using wastewater and agricultural wastes has been evaluated by the political, economic, and envrionmental impacts [4]. Reseach on the application of WTE system to increase the yield of methane production from wastewater has been conducted [5].

Large quantities of waste biogas form wastewater treatment plants (WWTPs) allocated in a nearby huge petrochemical indusrial complex can be exploited as fully as possible. Benchmark Simulation Model No.2 (BSM2) containing the conventional WWTP layout and default control strategy has been modeled and the amounts of waste biogas available can be explicitly calculated [6]. Biogas utliziation at full-scale WWTPs in the Unite Sates has been indentified considering economic, technical, social or regulatory issues [7]. The application of solid oxide fuel cells operated on anaerobic digester derived biogas in WWTPs have been reported using the process modeling software [8]. Biogas can be converted into biomethane by various biogas upgrading technologies as removing carbon dioxide $\left(\mathrm{CO}_{2}\right)$ and other contaminants. Current technologies of biogas upgrading available on the industrial scale encompass adsorption, absorption, membrane separation, and cryogenic separation [9]. A comparative study of chemical absorption processes, each of which employs aqueous solution of monoethanoamine (MEA), sodium hydroxide, and potassium hydroxide, has been carried out to evaluate the environmental impact [10]. Furthermore, the simultaneous upgrading of biogas from the anaerobic digestion and treatment of digestate subject to the microalgalbacterial cultures have been investigated [11].

Biomethane produced from biogas upgrading processes can be transformed into biohydrogen which is an energy carrier and plays a defining role in the green industrial revolution [12]. The steam methane reforming (SMR) process is the most common method of producing hydrogen for large-scale industries, with great conversion efficiency. Hydrogen production methods are dividied into conventional technologies depending on fossil fuels and renewable technologies. About a half of the total hydrogen production amounts up to date has relied on the SMR process consuming methane, natural gas, or other 
methane-based gases [13]. However, the conventional SMR process dependent on fossil fuels is not the best route to account for clean industries because ascending order of magnitude increase in demand would accerelate the depleition of infinite reserves [14]. Therefore, researchers have been studying to substitute methan from fossil fuels with biomethane from biomass or waste materials to harness cleaner hydrogen. The distributed biohydrogen production from biomethane via the SMR process has been suggested and the results have detailed the availability of biomethane from WWTPs [15]. Furturemore, biomethane steam reforming process in membrane reactors has been represented to foster the production of high-grade hydrogen [16].

Produced biohydrogen can be converted into green electricity through fuel cells, which are underpinned by a flexible and modular technology and easily manipulated by from individual homes to lidustrial-scale complexes. Types of fuel cells consist of proton exhchange membrane fuel cell commonly used in residential heating systems, solid oxide fuel cell appropriate for large combined heat and power, molten carbonate fuel cell (MCFC) suitable for grid-scale electricity production, and phosphoric acid fuel cell which was the first fuel cell system for commercial-scale combined with heat and power. MCFCs have become a promising fuel cell system as the market leader for large-scale industries [17]. High temperature fuel cells such as MCFCs are interconnected with steam reforming process to utilize a variety of fuels including carbon monoxide (CO), $\mathrm{CO}_{2}$, any hydrocarbons as well as hydrogen [18]. MCFCs integrated with the subsidiary power generator such as Rankine cycle show the enhanced efficiency and a number of MCFC power plants are commercially operated in South Korea to generate green electricity in bulks [19]. Research on the removal of hydrogen sulphide, which is the most harmful component in biogas, has been conducted to satisfy MCFCs requirements in case biogas is supplied as the raw material [20]. The MCFC with gas turbine hybrid plant due to the high operating temerpature and pressure has been optimized in terms of thermal, economic, and environmental viewpoints [21]. Moreover, energy and exergy analyses for integrated MCFCs with Rankine cycle and a proton exchange membrane electrolyzer have been investigated considering a parametric study for the configuration of the system performance [22].

An EIP aims to construct a collaborative network of a number of companies with local communities in an attempt to reduce waste and simultaneously satisfy energy or utility demands. The concept of EIPs has occurred to consider the growing environmental concern and primary objectives are mainly to deal with recycle/resue such as by-products or wastes and optimize energy network and waster/wastewater network [23]. Some integrated networks of companies involoved in diverse industries can be designed with respect to heterogeneity of EIPs and diminish environmental impact under the implementation of enhancing sustainability [24].

Utlity supply networks (USNs) which play a critical role in industries are natural part of any petrochemical industrial complex in order to balance maintenance and operation needs among others. Utilities such as water, steam, and electricity are transferred between companies and various utility production processes from the inside and outside of USNs give challenges of the development of an optimal USN. The principal goal of USNs is to fulfill utility demands in all companies under the single or multiple objectives from an envrionemtal and/or economic point of view [25]. Steam utility in general is produced by fossil-based boilers and electricity and water utlities are generated by in-company turbines or exported from the external utility sources. In USNs, manufactures correspond to the source companies, which explicitly produce distinct types of steam, and demand markets match the sink companies, which only consume steam without the steam generation [26]. Uncertainites of utility demands for each company and raw material prices have been considered to develop optimal USNs by a stochastic programming [27, 28]. And, the creation of EIPs based on utility sharing in reality has been achieved to evaluate an official national pocily in the Netherlands [29]. Ulsan metropolitan city in South Korea has also applied for the 
implementation of EIPs containing numerous industries according to the Korean National Cleaner Production Center [30]. The development of an optimal heat utility network in an EIP has been practiced targeting for Yeosu petrochemical industrial complex over the minimization of the total energy costs [31]. Research on bio-energy product supply chain based on WTE approach have been performed in a case stydy in Iran and the assessment of the optimal biomass supply network has been verified from economic, social, and envrionmental perspectives [32, 33]. However, the collaboration of USNs and WTE network regarding the real petrochemical industrial complex and the exisiting WWTPs and the design of model-based integrated USNs and WTE network have been hardly studied.

Therefore, the purposes of this study are 1) to develop an integrated utility and waste-to-energy (IUWTE) network by employing USNs in a huge petrochemical industrial complex and neighboring WWTPs available and 2) to apply the proposed hybrid GWP pinch analysis for the IUWTE network to account for enviromnetal impact resulting in advanced graphical results. Therefore the resulting waste-toenergy (WTE) network included Three main subsystems in a row namely WWTP for biogas production with anerobic digestion, biogas upgrading process, and MCFC system combined with Rankine cycle. The WTE network aims to finally generate green electricity for satisfying energy demands in the optimized USNs. The developed IUWTE model uses two waste streams, which are wastewater in the WWTPs for biogas production and waste steam from the USNs for green electiricty generation via the MCFC system. The optimalintegration/interaction between the WTE network and the optimal USN are studied using techno economic as well as sustainability (namely global warming potential) aspects. The results show the feasibility of estibilishing advanced EIPs by meeting the needed energy demands in the IUWTE network without being contigent on the fossil fuels.

\section{Problem statement}

The purpose of this study is to construct an environmentally benign energy network based on waste streams by integrating an USN and a WTE network. Figure 1 shows the general framework of an IUWTE network. The structure of the existing USNs aims to satisfy energy demands by using energies, each of which is directly generated by turbines in USNs and imported from external sources based on fossil fuels. The proposed model combines a WTE network with USNs and harness green electricity from wasted steam and wastewater from USNs and the WTE network respectively. Produced green electricity is able to fulfill energy demands in the optimized USN (Figure 1 (A)). The IUWTE network is entirely underpinned by four process systems, each of which is an USN, a WWTP, a biogas upgrading process, and MCFC (Figure 2 (B)). Wastewater is treated by WWTPs and the resulting sludge produced in the WWTS are converted through anerobic digesters into biogas. Biogas is transformed into biomethane via a biogas upgarding process. Generated biogas from the biogas upgrading process and wasted steam from USNs go into an internal SMR process in the MCFC in order to produce green electricity, which is considered to satisfy energy demands in USNs. Companies allocated in USNs are technically divided into source companies and sink companies. Source companies operate boilers and enable to produce utilites. Sink companies, which do not have any boilers, import steam utility that is generated by source companies to meet their energy demands. Source companies are sorted out into three types (type A, type B, and type C). Type A can simultaneously produce very-high pressure steam and high-pressure steam, type B is able to generate highpressure steam, and type C only makes medium-pressure steam. A turbine is connected with a high-pressure steam header and produce lower pressure steam, water, and electricity. Indeed, lower pressure steam can be generated by not the turbine but a letdown valve. Boilers in USNs basically use fossil fuels to boiler 
water and the bulk of greenhouse gases such as $\mathrm{SO}_{\mathrm{x}}$ and $\mathrm{CO}_{2}$ are emitted in the air. A WWTP in this study is described by a plantwide BSM2 model in which anaerobic digester are used toproduce biogas [6, 34]. The WWTP model with real data including information related to wastewater approximately computes biogas flow rate and the ratio of methane to $\mathrm{CO}_{2}$. The biogas upgarding process efficiently removes $\mathrm{CO}_{2}$ and produces biomethane in high yield. The MEA process is employed to upgrade biogas in this research. The MEA process is undoubtedly the most versatile system for capturing $\mathrm{CO}_{2}$ in many industries and global implications of the MEA process have been shown [35]. Moreover, results from simulation of the MEA process have already demonstrated great efficiency of the $\mathrm{CO}_{2}$ removal [36]. Finally, MCFC system harness green electricity using produced biomethane and wasted steam from USNs. As aforementioned in the introduction part, MCFC is the high temperature fuel cell and the most suitable system for large-scale electricity production. Hydrogen and hydrocarbons from internal SMR process and water gas shift reaction are converted into electricity via fuel cells [37]. Rankine cycle is combined with MCFC to utilize high temperature gas discharged by MCFC and generates additional green electricity. Produced green energy from the IUWTE network is distributed into energy demands in USNs. 


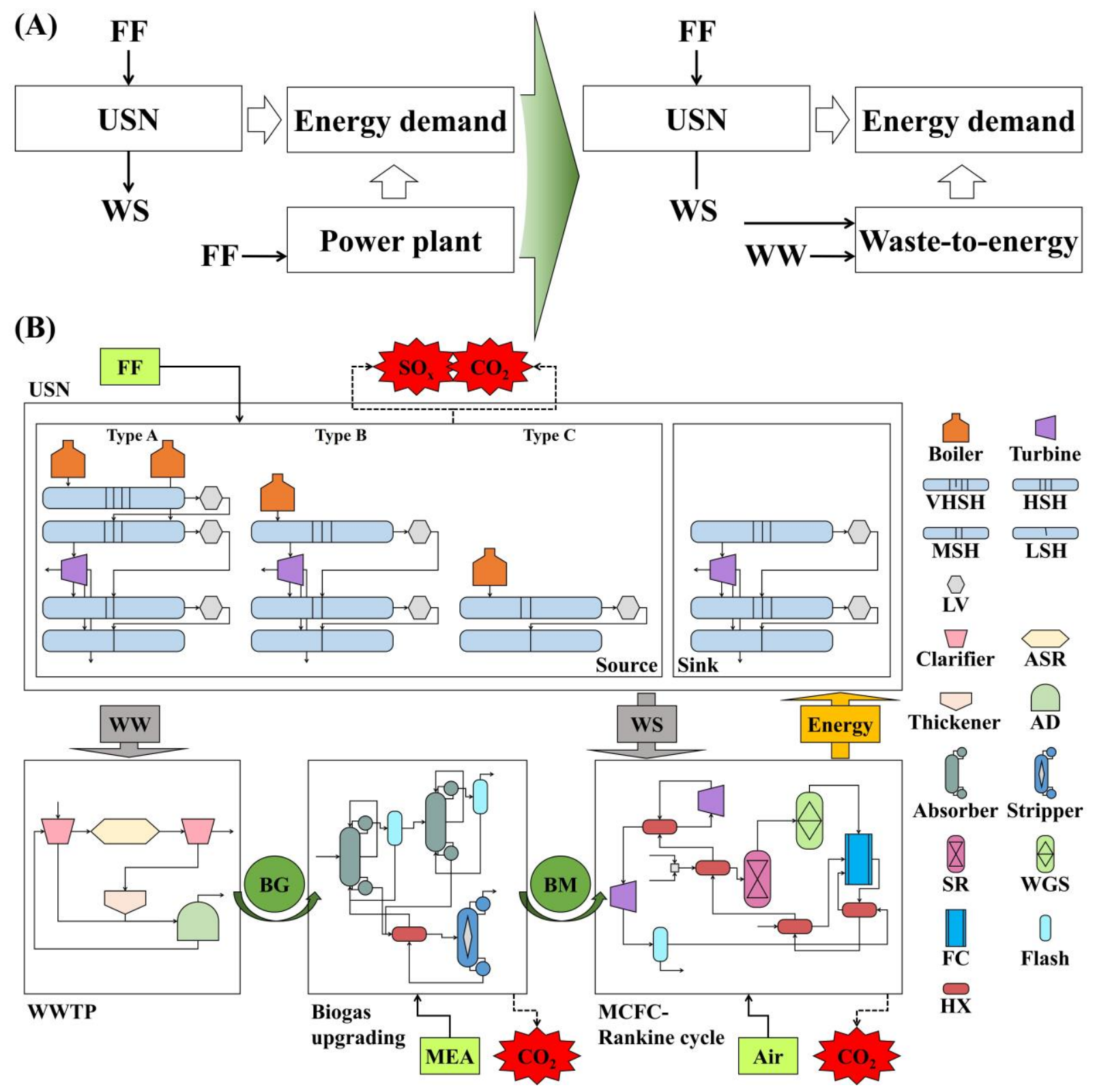

Figure 1. A framework of the IUWTE network; (A): Comparison of the existing USNs and the integration of USNs with WTE network and (B): Specific diagram of the IUWTE network with unit operations. FF: fossil fuel; WS: wasted steam; WW: wastewater; BG: biogas; BM: biomethane; VHSH: very high-pressure steam header; HSH: high-pressure steam header; MSH: medium-pressure steam header; LSH: low-pressure team header; LV: letdown valve; ASR: activate sludge reactors; AD: anaerobic digester; SR: steam reforming; WGS: water gas shift reaction; FC: fuel cell; HX: heat exchanger.

\subsection{Modeling and tools integration to simulate the IUWTE network}

Figure 2 presents the suggested network model based on appropriate integration of several tools/modeling platforms of involved subsystems to describe the IUWTE network. WWTPs, the biogas upgrading process, and MCFC are simulated by MATLAB and Aspen Plus using process and kinetic 
paramters and one of the main results is the quantiy of green energy available. A mathematical model based on feasible green energy amounts is designed to optimize USNs and optimal USNs for minimizing total costs are constructed. Hybrid GWP pinch analysis is performed according to the optimal structure of USNs. Pinch analysis for carbon emission under energy sector planning has been researched [38]. Carbon pinch analysis under the electricity sector has been also suggested [39]. In this study, external GWP staying off of the USNs and internal GWP for each company in the USNs are logically investigated. As a result, the total depletion of GWP can be calculated and variations of the quantites of GWP for each company are graphically figured out.
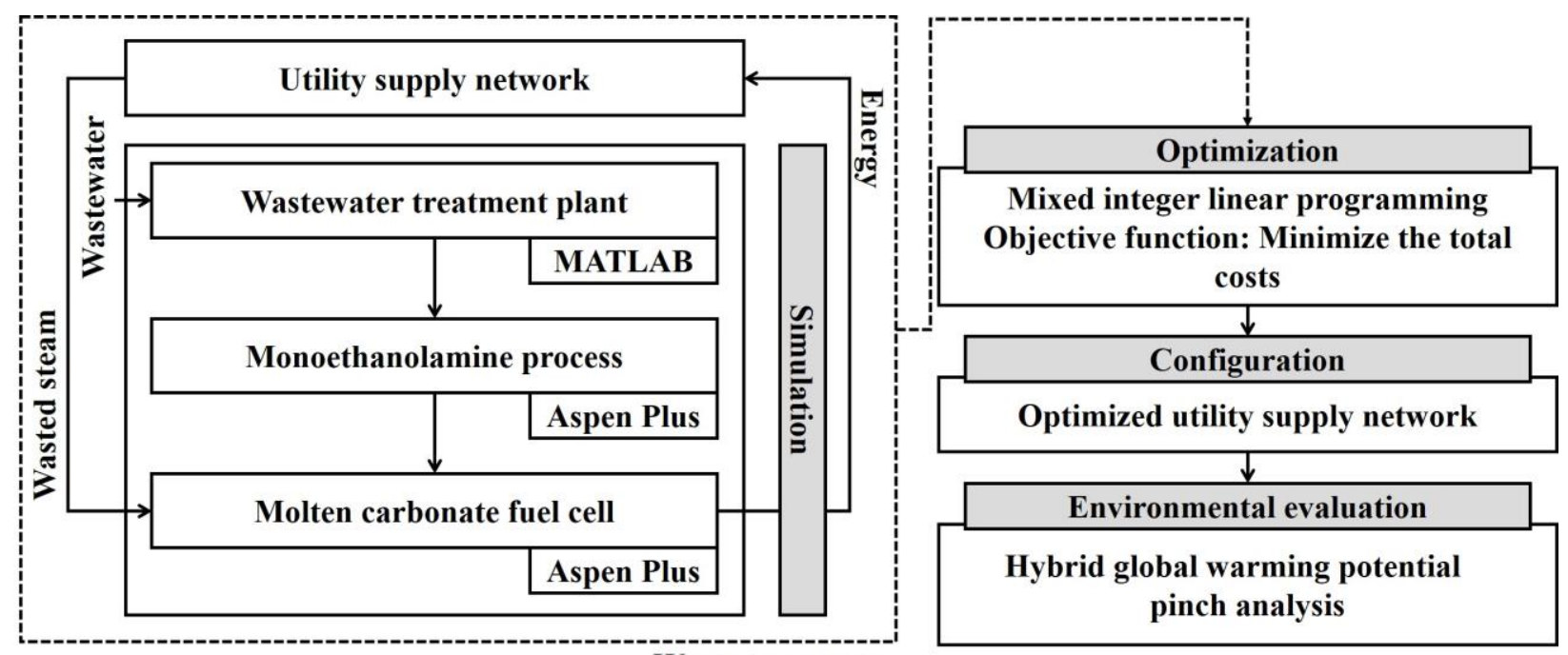

Waste-to-energy

Figure 2. The integrated model of the IUWTE network which is used to perform simulation for WTE network, optimization for USNs, configuration of optimal USNs, and environmental assessment based on hybrid GWP pinch analysis.

\section{The IUWTE network design}

The structure of the IUWTE network is divided into a process systems modeling part and an optimization part.

\subsection{Process systems modeling of the MEA process and the MCFC system with Rankine cycle}

This study has focused on modeling of MEA process and MCFC system, while theWWTPs and biogas production are modelled using the existing BSM2 model in matlab Simulink ${ }^{\circledR}$ commonly used for this purposes in literature(). Conventional MEA process consists of an absorber reactor and a stripper reactor. Main purpuose of the MEA process is efficiently to remove $\mathrm{CO}_{2}$ and reactions in each reactor are described in Table 1 (Eqs. (1) - (8)). Molar ratio of $\mathrm{CO}_{2}$ in biogas from the $\mathrm{BSM} 2$ model is about 0.35 and two consecutive absobers are cascaded to upgrade the purity of biomethane. All reactors in MEA process are rate-based equilibrium reactor and electrolyte non-random two-liquid model with Redlich-Kwong 
(eNRTL-RK) equation for property method is used. Recovery processes for MEA and water are coupled with each reactor to reuse materials as much as possible with respect to economic optimization.

Table 1. Property method, reactions, and specficiations of MEA process [40].

Property method

\begin{tabular}{|c|c|c|c|}
\hline \multicolumn{4}{|c|}{ Property method } \\
\hline & \multicolumn{3}{|c|}{ eNRTL-RK (Electrolyte NRTL model with Redlich-Kwong equation) } \\
\hline & \multicolumn{3}{|c|}{ MEA process } \\
\hline & Absorber & & Stripper \\
\hline & Reaction & & Reaction \\
\hline (1) & $M E A H^{+}+\mathrm{H}_{2} \mathrm{O} \leftrightarrow \mathrm{MEA}+\mathrm{H}_{3} \mathrm{O}^{+}$ & & \\
\hline (2) & $2 \mathrm{H}_{2} \mathrm{O} \leftrightarrow \mathrm{H}_{3} \mathrm{O}^{+}+\mathrm{OH}^{-}$ & & \\
\hline (3) & $\mathrm{HCO}_{3}^{-}+\mathrm{H}_{2} \mathrm{O} \leftrightarrow \mathrm{CO}_{3}^{2-}+\mathrm{H}_{3} \mathrm{O}^{+}$ & & \\
\hline (4) & $\mathrm{OH}^{-}+\mathrm{CO}_{2} \rightarrow \mathrm{HCO}_{3}^{-}$ & & Same as (1) to (7) \\
\hline (5) & $\mathrm{HCO}_{3}^{-} \rightarrow \mathrm{OH}^{-}+\mathrm{CO}_{2}$ & & \\
\hline (6) & $\mathrm{MEA}+\mathrm{CO}_{2}+\mathrm{H}_{2} \mathrm{O} \rightarrow \mathrm{MEACOO}+\mathrm{H}_{3} \mathrm{O}^{+}$ & $(8)$ & $\mathrm{H}_{2} \mathrm{O}+\mathrm{H}_{2} \mathrm{~S} \leftrightarrow H S^{-}+\mathrm{H}_{3} \mathrm{O}^{+}$ \\
\hline (7) & $\mathrm{MEACOO}-\mathrm{H}_{3} \mathrm{O}^{+} \rightarrow \mathrm{MEA}+\mathrm{CO}_{2}+\mathrm{H}_{2} \mathrm{O}$ & (9) & $\mathrm{H}_{2} \mathrm{O}+\mathrm{HS}^{-} \leftrightarrow \mathrm{S}^{2-}+\mathrm{H}_{3} \mathrm{O}^{+}$ \\
\hline
\end{tabular}

First absorber

Condenser temperature: $68^{\circ} \mathrm{C}$

Reflux ratio: 0.33

Reboiler temperature: $44^{\circ} \mathrm{C}$

Boilup ratio: 0.53

Second absorber

Condenser temperature: $62{ }^{\circ} \mathrm{C}$

Reflux ratio: 0.42

Reboiler temperature: $57^{\circ} \mathrm{C}$

Boilup ratio: 0.39

MCFC system included in this study contains four sub processes, each of which is internal SMR process, water gas shift reaction model, fuel cell system, and Rankine cycle and specific reactions are summarized in the Table 2. Biomethane from MEA process and waste steam from USNs are consumed in the SMR process and the removal of $\mathrm{CO}$ and the additional production of hydrogen are occurred in waste gas shift reaction (Eqs. (10) and (11)). Fundemantal reactions on the anode and the cathode allocated in a fuel cell system are represented in Eqs. (12) - (14). Methanation, CO hydrogenation, and Bouodouard reaction are additionally considered in order to design a robust MCFC (Eqs. (15) - (18)) [41].

Table 2. Property method, reactions, and specficiations of MCFC system [42].

Property method

\begin{tabular}{|c|c|c|c|}
\hline \multicolumn{4}{|c|}{ Property method } \\
\hline \multicolumn{4}{|c|}{ SRK (Soave-Redlich-Kwong) } \\
\hline \multicolumn{4}{|c|}{ Steam biomethane reforming process } \\
\hline & Reforming & & Water gas shift \\
\hline & Reaction & & Reaction \\
\hline (10) & $\mathrm{CH}_{4}+\mathrm{H}_{2} \mathrm{O} \rightarrow \mathrm{CO}+3 \mathrm{H}_{2}$ & (11) & $\mathrm{CO}+\mathrm{H}_{2} \mathrm{O} \rightarrow \mathrm{CO}_{2}+\mathrm{H}_{2}$ \\
\hline
\end{tabular}




\begin{tabular}{|c|c|c|c|}
\hline \multirow[b]{4}{*}{$(12)$} & \multicolumn{3}{|c|}{ Molten carbonate fuel cell system } \\
\hline & Anode & \multirow{4}{*}{$(14)$} & \multirow{3}{*}{$\begin{array}{c}\text { Cathode } \\
\text { Reaction } \\
O+2 C O+4 \rho^{-} \leftrightarrow 2 C O^{2-}\end{array}$} \\
\hline & Reaction & & \\
\hline & $\mathrm{H}_{2}+\mathrm{CO}_{3}^{2-} \leftrightarrow \mathrm{CO}_{2}+\mathrm{H}_{2} \mathrm{O}+2 e^{-}$ & & \\
\hline (13) & \multicolumn{2}{|c|}{$\mathrm{CO}+\mathrm{CO}_{3}^{2-} \leftrightarrow 2 \mathrm{CO}_{2}+2 e^{-}$} & \\
\hline \multicolumn{4}{|c|}{ Additional reaction } \\
\hline$(15)$ & \multicolumn{3}{|c|}{$\mathrm{CO}+\mathrm{H}_{2} \mathrm{O} \leftrightarrow \mathrm{CO}_{2}+\mathrm{H}_{2}$} \\
\hline (16) & \multicolumn{3}{|c|}{$\mathrm{CO}+3 \mathrm{H}_{2} \leftrightarrow \mathrm{CH}_{4}+\mathrm{H}_{2} \mathrm{O}$} \\
\hline$(17)$ & \multicolumn{3}{|c|}{$\mathrm{CO}+\mathrm{H}_{2} \leftrightarrow \mathrm{C}+\mathrm{H}_{2} \mathrm{O}$} \\
\hline (18) & \multicolumn{3}{|c|}{$2 \mathrm{CO} \leftrightarrow \mathrm{C}+\mathrm{CO}_{2}$} \\
\hline
\end{tabular}

Fuel cell operating temperature: $650{ }^{\circ} \mathrm{C}$

Power output $W$ produced from MCFC system can be calculated by Eq. (19). Multiplication of current density $C D$, total activate area of a fuel cell $A R_{\text {cell }}$, cell voltage $V_{\text {cell }}$, number of cells $N_{\text {cell }}$, and inverter efficiency from direct current to alternating current $I E$ determines the total power output $[37,43]$.

$W=C D \times A R_{\text {cell }} \times V_{\text {cell }} \times N_{\text {cell }} \times I E(19)$

In addition, Rankine cycle has been combined with the conventional MCFC to generate supplementary electricity because high temperature gas is discharged from the MCFC system.

\subsection{Mathematical model of the USN}

Green electricity from the MCFC combined with Rankine cycle is used to satisfy energy demands in USNs and simulatenously optimal structure of USNs is constructed by the mathematical model.

\subsubsection{Obejctive function}

The objective function in the mathematical model is to minimize the total economic costs $T C$ (Eq. (20)). The total economic costs consist of the total raw material costs $T R C$, the total capital costs for steam pipeline network $T C C$, and the total operating costs for steam pipeline network TOC. The total raw material costs are determined by the amounts of fuel consumption in a boiler $X_{f, f t, b, c}$, fuel price $F P_{f}$, amounts of $\mathrm{SO}_{\mathrm{x}}$ emission from a boiler $X_{b, c}^{S O_{x}}, \mathrm{SO}_{\mathrm{x}}$ treatment price $E C^{S O_{x}}$, amounts of $\mathrm{CO}_{2}$ emission from a boiler $X_{b, c}^{\mathrm{CO}_{2}}, \mathrm{CO}_{2}$ treatment price $E C^{C O_{2}}$, water amounts from external facilities to a water unit ${ }^{E x} X_{w n, c}^{\text {Water }}$, water purchase price $W P$, electricity amounts from external facilities to an electricity unit ${ }^{E x} X_{e n, c}^{E}$, 
electricity purchase price $E P$, and operating days $O D$ (Eq. (21)). The total capital costs for steam pipeline network are calculated by the binary variable whether a pipeline between two companies is installed or not $B_{s, h, c, c^{\prime}}$, fixed capital parameter $F C$, steam amounts between two companies $X_{s, h, c, c^{\prime}}$, variable capital parameter $V C$, operating days, distance between companies $D_{c, c^{\prime}}$, and depreciation factor $D F$ (Eq. (22)). The total operating costs for steam pipeline network are computed by the binary variable whether a pipeline between two companies is installed or not, fixed operating parameter $F O$, steam amounts between two companies, variable operating parameter $V O$, operating days, and distance between companies (Eq. (23)).

$$
\begin{gathered}
\text { Minimize TC }=T R C+T C C+T O C \\
T R C=\left\{\begin{array}{c}
\sum_{c} \sum_{b} \sum_{f t} \sum_{f}\left(F P_{f} \times X_{f, f t, b, c}\right)+\sum_{c} \sum_{b}\left(E C^{S O_{x}} \times X_{b, c}^{S O_{x}}+E C^{C O_{2}} \times X_{b, c}^{C O_{2}}\right) \\
+\sum_{c} \sum_{w n}\left(W P \times{ }^{E x} X_{w n, c}^{\text {Water }}\right)+\sum_{c} \sum_{e n}\left(E P \times{ }^{E x} X_{e n, c}^{E}\right)
\end{array}\right\} \times O D \\
T C C=\left(F C \times B_{s, h, c, c^{\prime}}+V C \times X_{s, h, c, c^{\prime}} \times O D\right) \times D_{c, c^{\prime}} / D F \quad c \neq c^{\prime} \\
T O C=\left(F O \times B_{s, h, c, c^{\prime}}+V O \times X_{s, h, c, c^{\prime}} \times O D\right) \times D_{c, c^{\prime}} \quad c \neq c^{\prime}
\end{gathered}
$$

\subsubsection{Fuel tanks in source company}

Fuel tanks are allocated only in source companies. The quanitites of fuel consumption in a boiler is less than or equal to the sum of fuel amounts in a boiler $X_{f, f t, c}$ and fuel inventory in a fuel tank $F I$ (Eq. (24)).

$$
X_{f, f t, b, c} \leq X_{f, f t, c}+F I \quad c \in \text { SOURCE }
$$

\subsubsection{Boilers to produce steam in source company}

Boilers are also included only in source companies. The amounts of steam generation from boiler $X_{s, b, h, c}$ are determined by boiler efficiency $B F_{b}$, calorific values of fuels $C V_{f}$, and the amounts of fuel consumption in a boiler (Eq. (25)).

$$
\sum_{h} \sum_{s}\left(X_{s, b, h, c} \times B F_{b}\right)=\sum_{f t} \sum_{f}\left(C V_{f} \times X_{f, f t, b, c}\right) \quad c \in \text { SOURCE }
$$


The sum of amounts of fuel consumption in a boiler and water consumption in a boiler $X_{w n, b . c}^{\text {Water }}$ is equal to the sum of amounts of steam generation from a boiler $X_{s, b, h, c}$, greenhouse gas emission from a boiler (Eq. (26)).

$$
\sum_{h} \sum_{s}\left(X_{s, b, h, c}+X_{b, c}^{S O_{x}}+X_{b, c}^{C O_{2}}\right)=\sum_{f t} \sum_{f} \sum_{w n}\left(X_{f, f t, b, c}+X_{w n, b . c}^{\text {Water }}\right) \quad c \in \text { SOURCE }
$$

The amounts of $\mathrm{SO}_{\mathrm{x}}$ and $\mathrm{CO}_{2}$ emissions from a boiler are calculated by the amounts of fuel consumption in a boiler, $\mathrm{SO}_{\mathrm{x}}$ emission parameter $E P_{f}^{S O_{x}}$ and $\mathrm{CO}_{2}$ emission parameter $E P_{f}^{\mathrm{CO}_{2}}$ (Eqs. (27) and (28))

$$
\begin{aligned}
X_{b, c}^{S O_{x}}=\sum_{f t} \sum_{f}\left(E P_{f}^{S O_{x}} \times X_{f, f t, b, c}\right) & c \in \text { SOURCE } \\
X_{b, c}^{C O_{2}}=\sum_{f t} \sum_{f}\left(E P_{f}^{C O_{2}} \times X_{f, f t, b, c}\right) & c \in \text { SOURCE }
\end{aligned}
$$

The amounts of necessary energy in a boiler $X_{e n, b, c}^{E}$ are determined by the binary variable whether a boiler is operated or not $B_{s, b, h, c}$, fixed consumption parameter of electricity in a boiler $F C P_{b}^{E}$, the amounts of steam generation from a boiler, and variable consumption parameter of electricity in a boiler $V C P_{b}^{E}$ (Eq. (29)).

$$
X_{e n, b, c}^{E}=F C P_{b}^{E} \times B_{s, b, h, c}+V C P_{b}^{E} \times X_{s, b, h, c} \quad c \in S O U R C E
$$

The amounts of steam generation from a boiler are limited by the binary variable whether a boiler is operated or not, minimum steam production capacity $M I N S P_{b, c}$, and maximum steam production capacity $M A X S P_{b, c}$ according to the types of boilers and source companies (Eq. (30)).

$$
\operatorname{MINSP}_{b, c} \times B_{s, b, h, c} \leq X_{s, b, h, c} \leq \operatorname{MAXSP} P_{b, c} \quad c \in \text { SOURCE }
$$

The relation between the binary variable whether a boiler is operated or not and the amounts of steam generation from a boiler is linearly relaxed as the following (Eq. (31)). 


$$
B_{s, b, h, c} / B N \leq X_{s, b, h, c} \leq B_{s, b, h, c} \times B N \quad c \in S O U R C E
$$

\subsubsection{Steam headers for different types of steam}

For all types of companies, the steam amounts in a steam header $X_{s, h, c}$ should be greater than or equal to steam demand $S D_{s, c}$ (Eq. (32)).

$$
S D_{s, c} \leq X_{s, h, c}
$$

Steam headers are separated into very high-pressure steam header, high-pressure steam header, medium-pressure steam header, and low-pressure steam header regarding the pressure levels and incorporate distinct mass balances according to the types of companies in USNs. Very-high pressure steam is directly produced by a boiler $X_{" V H S ", " B l^{\prime, " V H S H ", c}}$ and used to fulfill very-high pressure steam demands $X_{\text {"VHS","VHSH",c }}$ or transferred to a valve for the pressure down $X_{\text {"VHS","VHSH","VI",c }}$ (Eq. (33)). Source companies in type A have boilers to generate very-high pressure steam.

$$
X_{\text {"VHS","BI","VHSH",c }}=X_{\text {"VHS","VHSH",c }}+X_{\text {"VHS","VHSH","VI",c }} \quad c \in T A
$$

Source companies of type A contain the other boilers which are able to harness high-pressure steam. Therefore, the amounts of high-pressure steam released by a letdown valve connected with very high-

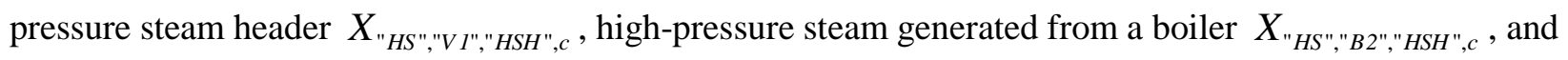
high-pressure steam transferred from other source companies $X_{" H S ", " H S H^{\prime, c}, c, c}$ are equal to the amounts of high-pressure steam to satisfy high-pressure steam demand $X_{" H S ", " H S H^{\prime \prime}, c}$, high-pressure steam to a turbine $X_{\text {"HS"," } H S H ", t, c}$, high-pressure stesam to a letdown valve $X_{\text {" } H S ", " H S H ", " V 2 ", c}$, high-pressure steam to other companies $X_{" H S ", " H S H ", c, c "}$, and wasted high-pressure steam $X_{" H S ", c}^{\text {Waste }}$ (Eq. (34)).

$$
\begin{aligned}
& X_{" H S ", " V l^{\prime,} " H S H ", c}+X_{" H S ", " B 2 ", " H S H ", c}+\sum_{c^{\prime}} X_{" H S ", " H S H ", c^{\prime}, c}=
\end{aligned}
$$

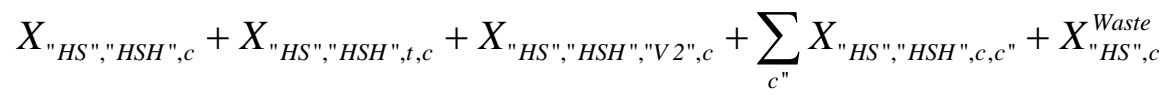

$$
\begin{aligned}
& c \in T A, c^{\prime} \in T A \vee T B, c^{\prime \prime} \in T A \vee T B \vee S I N K
\end{aligned}
$$


Source companies of type B do not include very high-pressure steam headers but encompass boilers to generate high-pressure steam. Therefore, the amounts of high-pressure steam produced from a boiler $X_{\text {" } H S \text { "," } B 3^{\prime, "} H S H ", c}$ and high-pressure steam from other companies are indentical to the amounts of highpressure steam to satisfy high-pressure steam demand, high-pressure steam to a turbine, high-pressure stesam to a letdown valve, high-pressure steam to other companies, and wasted high-pressure steam (Eq. (35)).

$$
\begin{aligned}
& X_{" H S ", " B 3 ", " H S H ", c}+\sum_{c^{\prime}} X_{" H S^{\prime,}, " H S H ", c^{\prime}, c}=
\end{aligned}
$$

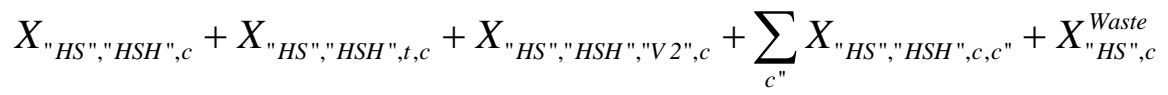

$$
\begin{aligned}
& c \in T B, c^{\prime} \in T A \vee T B, c^{\prime \prime} \in T A \vee T B \vee S I N K
\end{aligned}
$$

Mass balances for medium-pressure stesm in source companies of types A and B have equal to each other but source companies type $\mathrm{C}$ present other mass balance for medium-pressure steam. In the case of types $\mathrm{A}$ and $\mathrm{B}$, the amounts of medium-pressure stesam from the turbine $X_{" M S ", t, " M S H ", c}$, mediumpressure steam from a letdown valve $X_{" M S ", " V 2 ", " M S H ", c}$, and medium-pressure steam from other companies $X_{" M S^{\prime, "} M S H^{\prime, c}, c}$ are equal to the amounts of medium-pressure stesam to meet medium-pressure steam demands $X_{\text {"MS","MSH",c }}$, medium-pressure steam to a letdown valve $X_{\text {"MS","MSH","V3",c }}$, medium-pressure steam to other companies $X_{" M S ", " M S H^{\prime, c, c}}$, and wasted medium-pressure stesam $X_{" M S ", c}^{\text {Waste }}$ (Eq. (36)).

$$
\begin{gathered}
X_{" M S ", t, " M S H ", c}+X_{" M S ", " V 2 ", " M S H ", c}+\sum_{c^{\prime}} X_{" M S ", " M S H ", c^{\prime}, c}= \\
X_{" M S^{\prime \prime, " M S H ", c}}+X_{" M S ", " M S H ", " V 3^{\prime \prime, c}}+\sum_{c^{\prime \prime}} X_{" M S ", " M S H ", c, c^{\prime \prime}}+X_{" M S S^{\prime, c}}^{\text {Waste }} \\
c \in T A \vee T B, c^{\prime} \in S O U R C E, c^{\prime \prime} \in C
\end{gathered}
$$

Medium-pressure steam mass balance in source companies of type $\mathrm{C}$ indicates that the amounts of medium-pressure steam from a boiler $X_{\text {"MS","B4","MSH",c }}$ and medium-pressure steam from other companies are equal to the amounts of medium-pressure stesam to fulfill medium-pressure steam demands, mediumpressure steam to a letdown valve, medium-pressure steam to other companies, and wasted mediumpressure stesam (Eq. (37)).

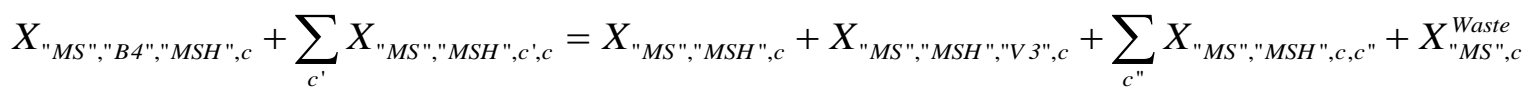

$$
\begin{aligned}
& c \in T C, c^{\prime} \in \operatorname{SOURCE}, c^{\prime \prime} \in C
\end{aligned}
$$


Low-pressure steam generation is not straight influenced by boilers. The amounts of low-pressure

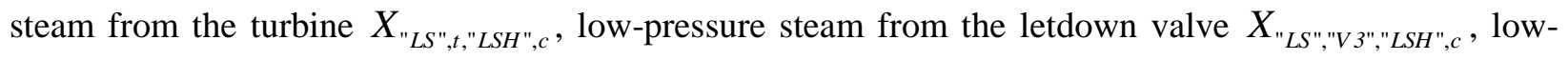
pressure stesam from other companies $X_{" L S ", " L S H ", c^{\prime}, c}$ are equal to the amounts of low-pressure steam to satisfy low-pressure steam demand $X_{\text {"LS"," } L S H ", c}$, low-pressure steam to other companies $X_{\text {"LS"," } L S H ", c, c^{\prime \prime}}$, and wasted low-pressures steam $X_{" L S ", c}^{\text {Waste }}$ (Eq. (38)).

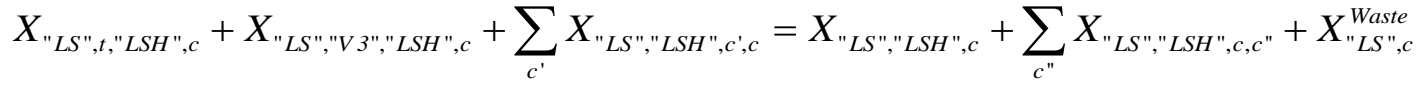

$$
\begin{aligned}
& c \wedge c^{\prime} \in \text { SOURCE, } c^{\prime \prime} \in C
\end{aligned}
$$

\subsubsection{Letdown valve to decrease steam pressure}

Steam pressure is able to be decreased by steam converting parameter $S C P_{s, s^{\prime}}$ using letdown valves (Eq. (39)). All steam headers except for the low-pressure steam header incorporate letdown valves.

$$
X_{s, v, h, c}=S C P_{s, s^{\prime}} \times X_{s^{\prime}, h^{\prime}, v, c} \quad s<s^{\prime}, h<h^{\prime}
$$

\subsubsection{Turbine to generate lower pressure steam, water, and electricity}

A turbine linked with high-pressure steam header can consume high-pressure steam vent $X_{" H S ", " H S H ", t, c}$ in order to make medium-pressure steam $X_{\text {"MS",t,"MSH", }}$, low-pressure steam, $X_{\text {"LS",t,"LSH",c}}$, and water $X_{t, w n, c}^{\text {Water }}$ (Eq. (40)). The amounts of produced water from the turbine is determined by the amounts of high-pressure steam vent with condensate parameter $C P$ (Eq. (41)). The amounts of electricity from the turbine $X_{t, e n, c}^{E}$ is calculated by turbine parameters for steam types $T P_{s}$, turbine parameter for water $T P^{\text {Water }}$, and amounts of steam and water associated with the turbine (Eq. (42)).

$$
\begin{aligned}
& X_{" H S ", " H S H ", t, c}=X_{" M S ", t, " M S H ", c}+X_{" L S ", t, " L S H ", c}+\sum_{w n} X_{t, w n, c}^{\text {Water }} \quad c \notin T C \\
& \sum_{w n} X_{t, w n, c}^{\text {Water }}=C P \times X_{" H S ", " H S H ", t, c} \quad c \notin T C \\
& X_{t, e n, c}^{E}=T P_{" H S^{\prime}} \times X_{" H S^{\prime, " H S H ", t, c}}-T P_{" M S^{\prime \prime}} \times X_{" M S^{\prime,}, t, M S H^{\prime \prime}, c}-T P_{" L S "} \times X_{" H S^{\prime \prime}, t, " L S H^{\prime \prime}, c}-\sum_{w n}\left(T P^{\text {Water }} \times X_{t, w n, c}^{\text {Water }}\right) \\
& c \notin T C
\end{aligned}
$$




\subsubsection{Water unit to control water}

The amounts of water in a water unit $X_{w n, c}^{\text {Water }}$ should be greater than or equal to water demand $W D_{c}$ (Eq. (43)).

$$
W D_{c} \leq X_{w n, c}^{\text {Water }}
$$

The amounts of water from external water facilities ${ }^{E x} X_{w n, c}^{\text {Water }}$ and produced water from turbine $X_{t, w n, c}^{\text {Water }}$ are indentical to the amounts of water in the water unit and water consumption in boilers $X_{w n, b . c}^{\text {Water }}$ (Eq. (44)).

$$
{ }^{E x} X_{w n, c}^{\text {Water }}+X_{t, w n, c}^{\text {Water }}=X_{w n, c}^{\text {Water }}+\sum_{b} X_{w n, b . c}^{\text {Water }}
$$

\subsubsection{Electricity unit to manipulate electricity}

The amounts of electricity in an electricity unit $X_{e n, c}^{E}$ should be greater than or equal to electricity demand $E D_{c}$ (Eq. (45)).

$$
E D_{c} \leq X_{e n, c}^{E}
$$

The amounts of electricity from external energy sources based on fossil fuels ${ }^{E x} X_{e n, c}^{E}$, electricity generation from the turbine $X_{t, e n, c}^{E}$, and green electricity generation from IUWTE network ${ }^{M C F C} X_{e n, c}^{E}$ are equal to the amounts of electricity to electricity demands $X_{e n, c}^{E}$ and electricity consumption in boilers $X_{e n, b, c}^{E}$ (Eq. (46)). The quantites of green electricity should be less than or equal to the energy potential $W 2 E$ which is expected by using IUWTE network in aforementioned process modeling section (Eq. (47)).

$$
\begin{gathered}
{ }^{E x} X_{e n, c}^{E}+X_{t, e n, c}^{E}+{ }^{M C F C} X_{e n, c}^{E}=X_{e n, c}^{E}+\sum_{b} X_{e n, b, c}^{E} \\
\sum_{c} \sum_{e n}{ }^{M C F C} X_{e n, c}^{E} \leq W 2 E
\end{gathered}
$$




\subsubsection{Sink companies in the absence of boilers}

Sink companies do not contain boilers and import needed steam types from source companies in USNs or operate letdown valves to make lower pressure steam. High-pressure steam is inevitably transferred from source companies $X_{" H S^{\prime,}, H S H^{\prime \prime}, c^{\prime}, c}$ and it is consumed to satisfy high-pressure steam demands $X_{\text {" } H S^{\prime, "} H S H^{\prime \prime, c}}$, transports to a letdown valve $X_{\text {"HS"," HSH","V2",c }}$, or emitted as wasted steam $X_{\text {"Waste }}^{\text {Wh }, c}$ (Eq. (48)). The amounts of medium-pressure steam from other companies $X_{\text {"MS","MSH",c,c }}$ and mediumpressure from the letdown valve $X_{" M S ", " V 2 ", " M S H^{\prime, c}}$ are equal to the amounts of medium-pressure steam to meet medium-pressure demands $X_{" M S ", " M S H^{\prime \prime c}}$, medium-pressure steam to a letdown valve $X_{\text {"MS","MSH","V3",c }}$, and wasted medium-pressure steam $X_{" M S ", c}^{\text {Waste }}$ (Eq. (49)). The amounts of low-pressure steam from other companies $X_{\text {"LS","LSH",c,c }}$ and low-pressure from the letdown valve $X_{\text {"LS","V3","LSH",c }}$ are equal to the amounts of low-pressure steam to meet low-pressure demands $X_{\text {" } L S ", " L S H ", c}$ and wasted low-pressure steam $X^{\text {Waste }} L S ", c$ (Eq. (50)).

$$
\begin{aligned}
& \sum_{c^{\prime}} X_{" H S^{\prime,}, H S H^{\prime \prime}, c^{\prime}, c}=X_{" H S^{\prime,}, H S H^{\prime \prime, c}}+X_{" H S^{\prime \prime, " H S H ", " V 2 ", c}}+X_{" H S^{\prime \prime}, c}^{\text {Waste }} \quad c^{\prime} \in T A \vee T B
\end{aligned}
$$

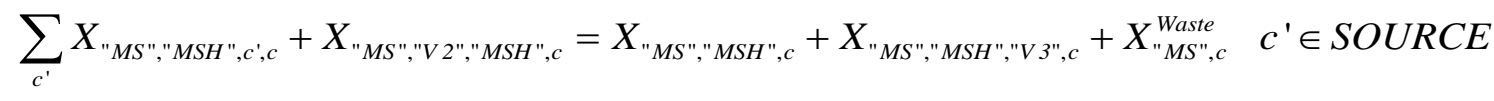

$$
\begin{aligned}
& \sum_{c^{\prime}} X_{" L S ", " L S H^{\prime, c}, c}+X_{" L S ", " V 3^{\prime \prime, " L S H ", c c}}=X_{" L S ", " L S H ", c}+X_{" L S ", c}^{\text {Waste }} \quad c^{\prime} \in S O U R C E
\end{aligned}
$$

\subsubsection{Steam transfer between companies}

The installation of pipelines between companies in USNs is linearly constrained by Eq. (51). Simultaneous utlity transfer in-between is not allowed (Eq. (52)).

$$
\begin{gathered}
B_{s, h, c^{\prime}, c} / B N \leq X_{s, h, c^{\prime}, c} \leq B_{s, h, c^{\prime}, c} \times B N \quad c \neq c^{\prime} \\
B_{s, h, c^{\prime}, c}+B_{s, h, c, c^{\prime}} \leq 1 \quad c \neq c^{\prime}
\end{gathered}
$$

\subsubsection{Waste steam generation for the IUWTE network}

Wasted steam from steam headers in USNs should be sufficiently generated to play a role of input component for the internal SMR of MCFC in the IUWTE network as well as react with biomethane from MEA process in the IUWTE network. The quantities of wasted steam from USNs are manipulated by steamto-carbon ratio $S 2 C R$ and biomethane potential $\mathrm{BIOCH} 4$ determined in the IUWTE network (Eq. (53)). 


$$
\text { BIOCH } 4 \times S 2 C R \leq \sum_{c}\left(X_{" H S^{\prime \prime, ~}}^{\text {Waste }}+X_{" M S ", c}^{\text {Waste }}+X_{" L S ", c}^{\text {Waste }}\right)
$$

\section{Case study}

A case study of Yeosu petrochemical industrial complex in South Korea has been applied for this study. A number of companies are allocated within Yeosu industry and various neighboring WWTPs are placed near Yeosu industry (Figure 3 (A)). 15 chemical companies in which utility demand data are discolosed have been selected as components of the USN in this case study. The USN comprises10 source companies able to produce utilities and 5 sink companies unable to generate utilities (Figure 3 (B)). The total capacity availiable of WWTPs to treat wastewater is about 299,020 ton per day and average daily treatment flow rate is approximately 233,280 ton per day. WWTPs are divided into large-scale WWTPs and medium-size WWTPs according to the general standard of the total capacity of daily wastewater treatment amounts, 500 tons per day. The number of large-scale WWTPs is a total of 6 and the number of medium-scale WWTPs is a total of 10, respectively (Figure 3 (C)). Specific capacities and average daily treatment flow rates of wastewater from open data in Korea Environment Corporation are described in Table 3.

(A)

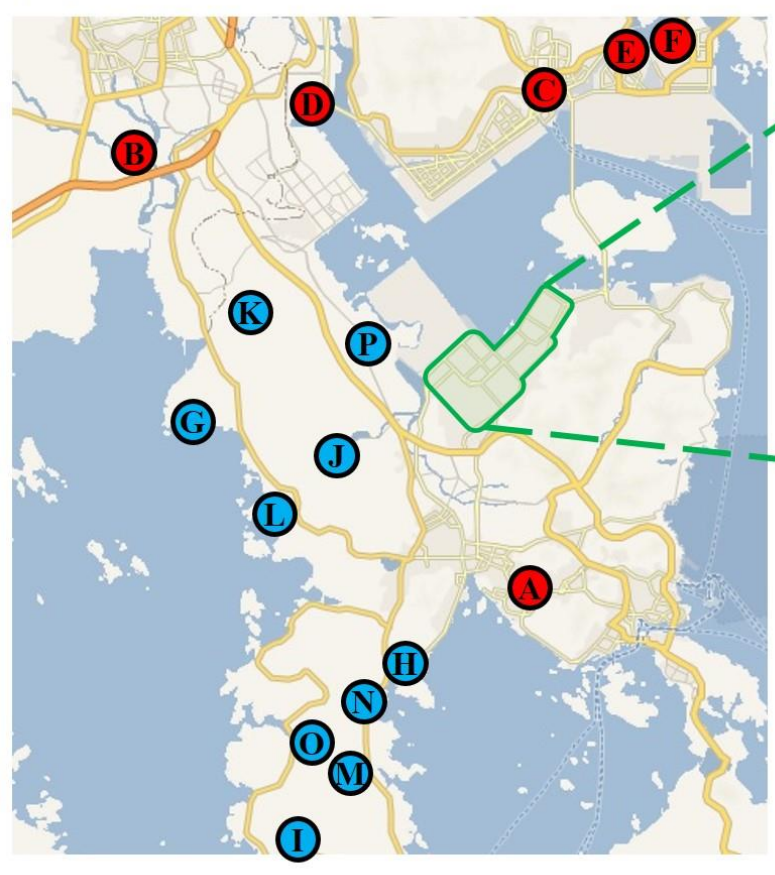

A to F: WWTP over 500 tons/day G to P: WWTP below 500 tons/day
(B)

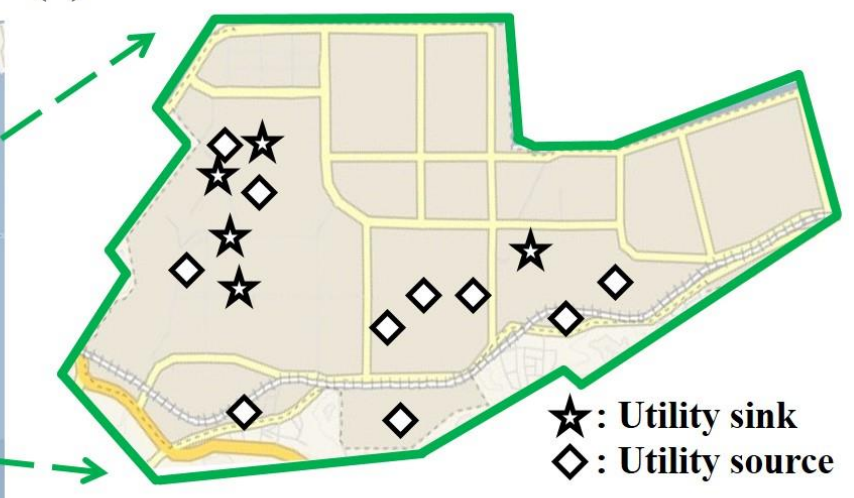

(C)

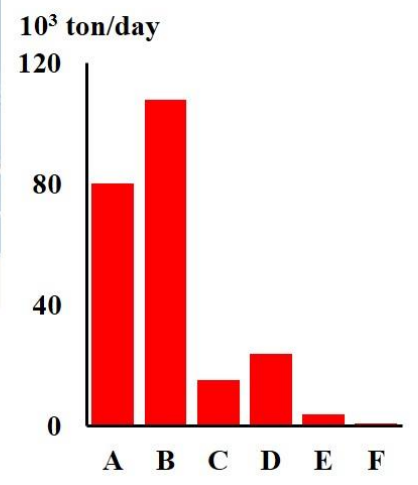


Figure 3. Yeosu petrochemical industrial complex and WWTPs available in the vicinity for a case study; (A): Distribution of WWTPs and Yeosu industry on the real map, (B): Sink and source companies in the USN, and (C): Average daily flow rate of wastewater treatment for large-scale WWTPs and medium-size WWTPs.

Table 3. A comparison of capacity and average daily treatment flow rate of wastewater for individual WWTP employed in the case study.

\begin{tabular}{cccc}
$\begin{array}{c}\text { Size of WWTP } \\
\text { (over 500 tons/day) }\end{array}$ & Name of WWTP & Capacity (ton/day) & $\begin{array}{c}\text { Average daily treatment flow rate } \\
\text { of wastewater (ton/day) }\end{array}$ \\
\hline A & Yeosu & 110,000 & 80,301 \\
B & Suncheon & 130,000 & 107,926 \\
C & Jungang & 25,000 & 15,345 \\
D & Gwangyang A & 24,000 & 24,063 \\
E & Gwangyang B & 7,500 & 3,969 \\
F & Jinwol & 1,600 & 1,022 \\
\hline Size of WWTP & & & \\
(below 500 tons/day) & & & 55 \\
\hline G & Gwangam & 70 & 61 \\
H & Yongju & 80 & 128 \\
I & Najin & 180 & 45 \\
J & Seochon & 60 & 57 \\
K & Gajang & 80 & 40 \\
L & Gunghang & 60 & 75 \\
M & Hwadong & 100 & 37 \\
N & Jangsu & 50 & 59 \\
O & Bongdu & 80 & 97 \\
P & Sangok & 160 &
\end{tabular}

As aforementioned in the problem statement section, source companies in the USN have three different types and main process units can be altered depending on the type. All companies require steam, water, and electricity demands and in the case of steam demand, 4 pressure levels separate steam demand table (Table 4). Types of boilers, which are only built in source companies, depends on the types of source companies. Boiler types B1 and B2 are used to produce very high-pressure steam and high-pressure steam respectively in source company type A. Boiler type B3 is utilized to generate high-pressure steam in source company type B. Source company type C operates boiler type B4 to make medium-pressure steam. The first company in source company type B has utility production ability but does not have any utility demand according to the reference data.

Table 4. Classification of main process units and utility demand data of source and sink companies in the existing USN. VHS: Very high-pressure steam, HS: High-pressure steam, MS: Medium-pressure steam, LS: Low-pressure steam, HSH: High-pressure steam header, MSH: Medium-pressure steam header, and LSH: Low-pressure steam header.

Utility demand

Main process unit ton/day $\quad \mathrm{kWh} / \mathrm{day}$




\begin{tabular}{|c|c|c|c|c|c|c|c|c|c|c|}
\hline Source & & Boiler & $\begin{array}{l}\text { Steam } \\
\text { header }\end{array}$ & Turbine & VHS & HS & MS & LS & Water & Energy \\
\hline \multirow{5}{*}{ Type A } & 1 & \multirow{5}{*}{ B1, B2 } & \multirow{5}{*}{ All } & \multirow{5}{*}{$\mathrm{O}$} & & & 2,033 & 3,089 & 1,322 & 2,211 \\
\hline & 2 & & & & 9,933 & 9,933 & & & 5,522 & 2,644 \\
\hline & 3 & & & & 9,933 & 12,011 & 3,800 & 2,544 & 4,856 & 2,644 \\
\hline & 4 & & & & 13,467 & 4,944 & 4,656 & 2,522 & 5,522 & 4,411 \\
\hline & 5 & & & & 9,300 & 1,633 & 1,456 & 1,567 & 4,411 & 3,756 \\
\hline \multirow[t]{2}{*}{ Type B } & $\begin{array}{l}1 \\
2\end{array}$ & \multirow[t]{2}{*}{ B3 } & $\begin{array}{c}\text { HSH, } \\
\text { MSH, LSH }\end{array}$ & \multirow[t]{2}{*}{$\mathrm{O}$} & & 2,544 & 756 & 311 & 2,211 & 1,544 \\
\hline & 1 & & & & & & & 556 & 1,100 & 1,100 \\
\hline \multirow[t]{2}{*}{ Type C } & 2 & \multirow[t]{2}{*}{ B4 } & MSH, LSH & \multirow[t]{2}{*}{$X$} & & & 3,711 & 2,122 & 1,100 & 1,544 \\
\hline & 3 & & & & & & 689 & 4,044 & 1,322 & 1,100 \\
\hline \multicolumn{11}{|l|}{ Sink } \\
\hline \multirow{5}{*}{ Sink } & 1 & \multirow{5}{*}{$X$} & \multirow{5}{*}{$\begin{array}{c}\text { HSH, } \\
\text { MSH, LSH }\end{array}$} & \multirow{5}{*}{$\mathrm{O}$} & & & 778 & & & 1,100 \\
\hline & 2 & & & & & & 1,322 & 1,100 & 1,322 & 2,211 \\
\hline & 3 & & & & & & 311 & 444 & & 1,100 \\
\hline & 4 & & & & & & & 133 & & 444 \\
\hline & 5 & & & & & 1,433 & 1,011 & 156 & 2,644 & 2,211 \\
\hline
\end{tabular}

The case study has assumed that WWTPs everywhere in the vicinity of Yeosu petrochemical industrial complex can be integrated with USNs and in case external energies are exported and consumed to satisfy energy demands in USNs, $0.68 \mathrm{~kg}$ of carbon per $\mathrm{kWh}$ is approximately emitted [44]. The professional optimization tool, GAMS version 24.6 with the CPLEX solver, has conducted the optimization of USNs [45].

\section{Results and discussion}

A WWTP model which has been designed depending on the BSM2 model is applied for neighboring WWTPs near Yeosu industry. The total quantites of biogas generation according to the simulation results are approximately 30 tons per day and mole fracionts of biomethane and $\mathrm{CO}_{2}$ are 0.65 and 0.35 , respectively.

\subsection{Simulation results of the MEA process and the MCFC system combined with Rankine cycle}

Figure 4 shows the results of the MEA process simulation conducted in this case study. Two absorbers in a row are connected to extract high yield of biomethane from biogas and the stripper captures almost all of $\mathrm{CO} 2$ in biogas. Absorbers use make-up water and make-up MEA to efficiently balance the chemical reactions in the reactors and discharged water by flash drums is reused in the absorbers. Rich amine streams from absorbers are mixed and enter the stripper as an input stream, as a result, $\mathrm{CO}_{2}$ is separated from the mixed input stream. Lean amine stream including MEA in bulks is also recycled to maintain optimal operations. Main streams in the MEA process are marked by from A to I and mole fractions of crucial components in each stream are presented in Figure 4. Stream A is the biogas stream from a WWTP based on BSM2 model and has 0.65 mole fraction of biomethane and 0.35 mole fraction of $\mathrm{CO}_{2}$. Steam $\mathrm{B}$ is the output gas stream from the first absorber and indicates 0.60 mole fraction of biomethane, 0.14 mole fraction of $\mathrm{CO}_{2}$, and 0.30 mole fraction of water. Huge amounts of water are separated by the 
first flash drum and stream $\mathrm{C}$ passing through a compressor and a heat exchanger contains 0.77 mole fraction of biomethane, 0.20 mole fraction of $\mathrm{CO}_{2}$, and 0.03 mole fraction of water. Stream $\mathrm{D}$ from the second absorber which will provide one of the input streams into the MCFC system includes 0.92 mole fraction of biomethane, 0.05 mole fraction of $\mathrm{CO}_{2}$, and 0.03 mole fraction of water. Streams $\mathrm{F}$ and $\mathrm{G}$ are make-up water streams with one mole fraction of water and streams $\mathrm{H}$ and I are make-up MEA streams with 0.61 mole fraction of MEA and 0.51 mole fraction of MEA, resulting from design specification technique in Aspen Plus. A total of 5 recycle streams is considered to reuse MEA and water as much as possible. As a result, 1,200 $\mathrm{kg}$ of MEA per day and 1,100 kg of water per day are approximately recycled into the MEA process. With respect to the energy consumption, the total $25,733 \mathrm{kWh}$ per day is used to operate heat exchangers, compressor, pump, condensers, reboilers, and flash drums.

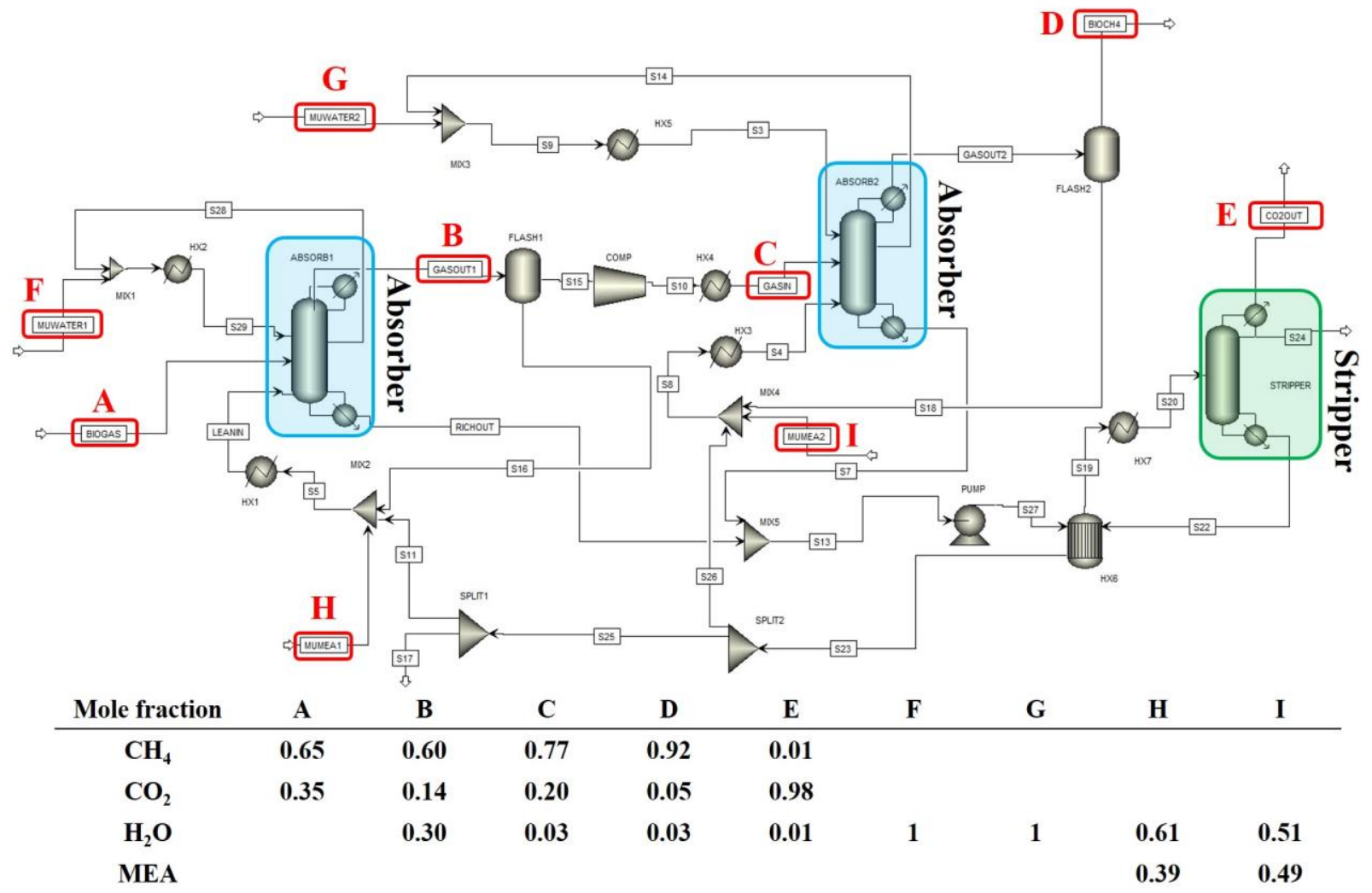

Figure 4. Simulation results of the MEA process performed in the case study and mole fractions of principal components in main streams.

The simulation results of the MCFC system combined with Rankine cycle are illustrated in Figure 5. Biomethane from the MEA process and waste steam from the USNs are mixed and consumed in the internal SMR process. Water gas shift reaction is employed to reduce the ratio of $\mathrm{CO}$ and increase amounts of hydrogen since the gas from the internal SMR process encompasses great quantities of CO. The gas generated from water shift gas reaction system goes into the high temperature fuel cell. The fuel cell system is designed depending on Eqs. (12) to (18) and the equilibrium reactor has been considered to construct the fuel cell because all reactions are assumed to react on the phase equilibrium which is a common assumpition 
used in process systems modeling. The high temperature gas from the fuel cell can be suitable for Rankine cycle to obtain supplementary green electricity and recycled into the fuel cell system. Main streams and mole fraction of important materials in the MCFC system are as followings. Steam A coupled with the output stream in the MEA process has 0.92 mole fraction of biomethane. 0.05 mole fraction of $\mathrm{CO}_{2}$, and 0.03 mole fraction of water. Steam B consists of wasted steam from the USNs and the amounts of needed steam are determined by the steam to carbon ratio, which is assumed as 3 in this study. Stream $\mathrm{C}$ from the internal SMR process contains 0.35 mole fraction of water, 0.49 mole fraction of hydrogen, and 0.16 mole fraction of CO. Stream D includes 0.05 mole fraction of $\mathrm{CO}_{2}, 0.29$ mole fraction of water, 0.54 mole fraction of hydrogen, and 0.10 mole fraction of CO. Green electricity generation by the MCFC system can be calculated by Eq. (19). The total green electricity amounts encompassing additional green electrcitiy generation by Rankine cycle are about $111,996 \mathrm{kWh}$ per day. Indeed, the net green electrcitiy output except for energy consumptions in the MEA process, the internal SMR process as well as other facilities are approximately $41,339 \mathrm{kWh}$ per day.

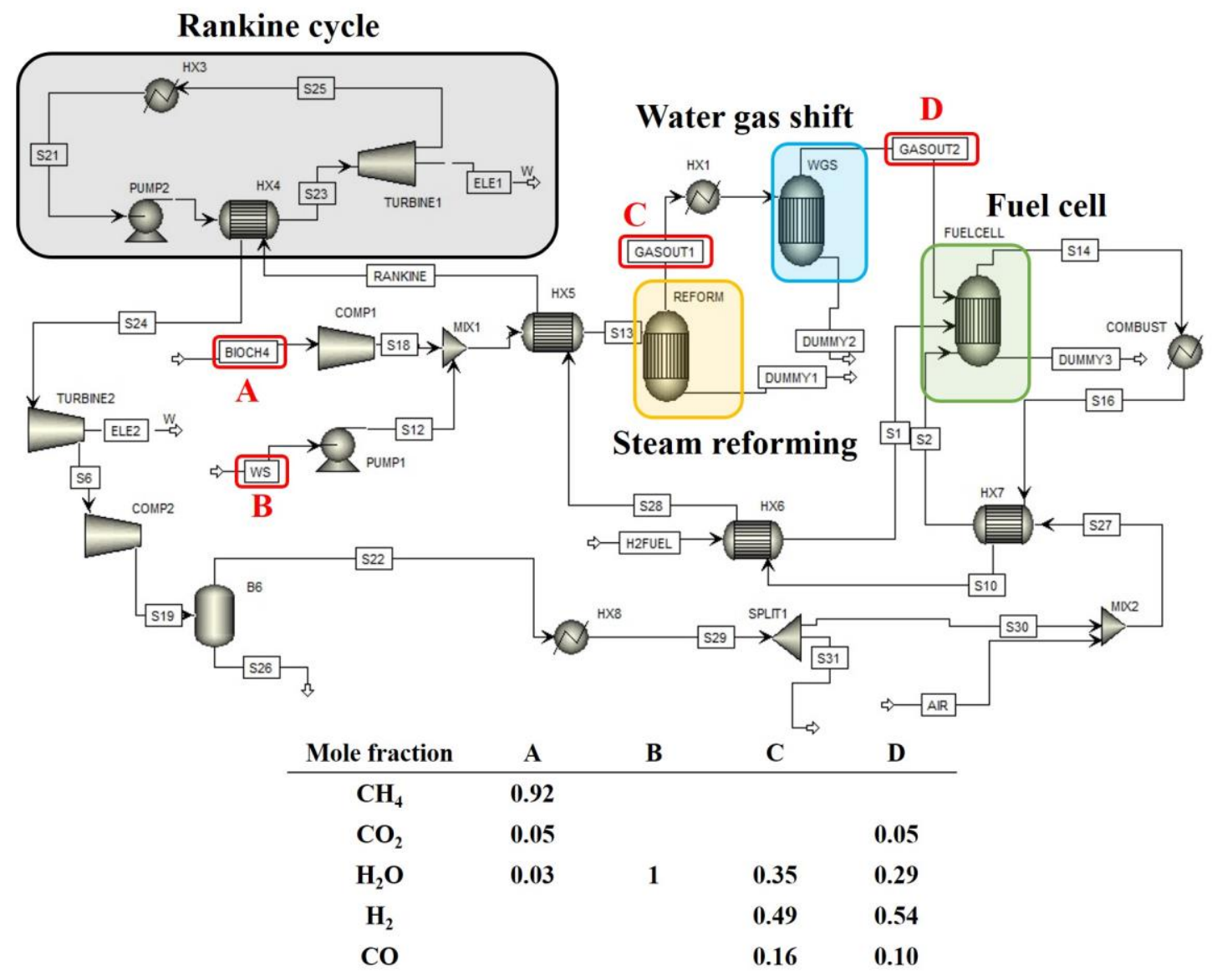

Figure 5. Simulation results of the MCFC system with Rankine cycle suggested in the case study and mole fractions of principal components in main streams.

\subsection{Optimization results of the optimal USN based on the IUWTE network}


As aforementioned in the mathematical model part, the developed mathematical model to optimize the USNs includes the constraints for the net electiricty potential from the MCFC system combined with Rankine cycle based on the consumption of waste steam from the USNs. The optimal USN structure of Yeosu petrochemical industrial complex is depicted in Figure 6. Steam utlity is transmitted between source companies in the close distance as well as from source companies to sink companies. Source companies A4 and A5 have great utility demands compared to other companies according to the Table 4. Therefore, they have decided on direct steam production and consumption instead of participating in USNs. Even though source company B1 does not need to satisfy any utility demand, it generates and distributes highpressure steam to near sink companies in order to meet their steam utility demands. Sink companies S1, S2, and S4 do not have high-pressure steam demands; however, high-pressure steam transferred from B1, A1, and $\mathrm{A} 2$ is utilized to fulfill medium-pressure steam or low-pressure steam demands by operating turbines or letdown valves. Source companies A1 and A2 have great capacities of the maxium steam production otherwise they have relatively lower steam utlity demands compared to other source companies of type A, and companies in the vicinity of A1 and A2 can import extra steam available from A1 and A2. The total economic costs of the optimal USN in this study is $147,071,200$ US\$ per year and about $15 \%$ of the total costs are reduced compared to those of the existing USN, 169,198,582 US\$ per year [25].

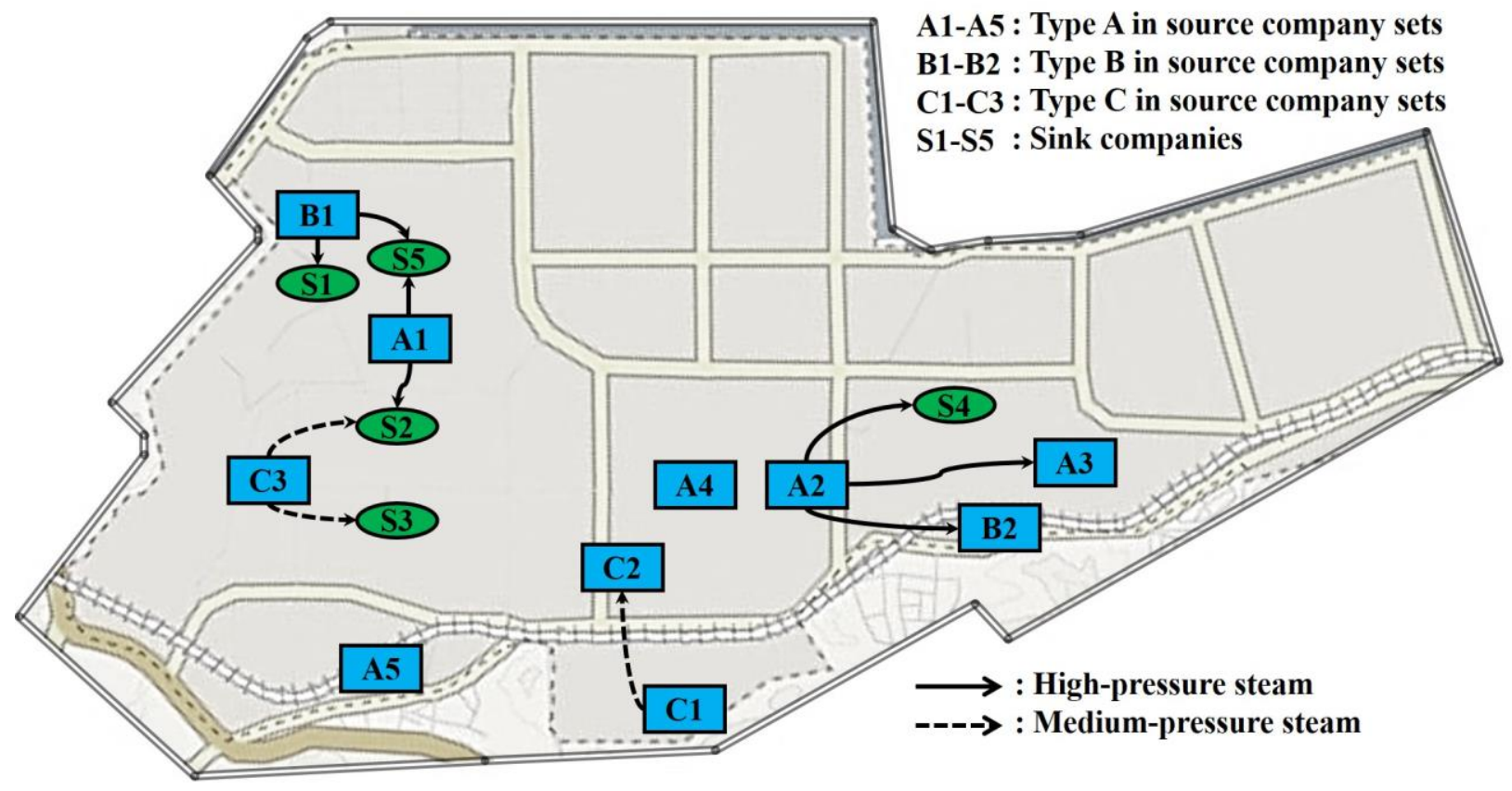

Figure 6. The strucuture of optimal USN based on the IUWTE network in the case study.

The flow rates of input and output materials in the IUWTE network are described in the Table 5. The total wastewater amounts treated in WWTPs allocated near aside Yeosu petrochemical industrial complex are 233,280 tons per day and about $29,383 \mathrm{~kg}$ of biogas per day can be extracted by anaerobic digesters in WWTPs. The total quantities of main components used in the MEA process as a biogas upgrading process are 29,383 kg biogas from WWTPs per day, 28,996 kg of make-up MEA per day, and $666 \mathrm{~kg}$ of make-up water per day. Produced biomethane stream from the MEA process has 12,036 $\mathrm{kg}$ of biomethane per day and $4,929 \mathrm{~kg} \mathrm{CO}_{2}$ per day is captured by the stripper in the MEA process. The MCFC 
system consumes $12,036 \mathrm{~kg}$ of biomethane from the previous MEA process per day, 40,662 $\mathrm{kg}$ of waste steam from the USNs per day, and $1,740 \mathrm{~kg}$ of hydrogen inventory per day to manage high temperature reactors. About $1,112 \mathrm{~kg}$ of $\mathrm{CO}_{2}$ per day is emitted from the MCFC system and the total green electricity generation is approximately $41,339 \mathrm{kWh}$ per day excluding energy consumptions in other processes. The optimized USN exploits the total 4,797 tons of fossil fuels per day and 117,504 tons of water per day, emits 44 tons of $\mathrm{CO}_{2}$ per day and 51 tons of $\mathrm{SO}_{x}$ per day, and vent 40,662 $\mathrm{kg}$ of wasted steam per day under the constraints of fulfilling utility demands and transmitting necessary waste steam into the MCFC system.

Table 5. Simulation and optimization results of input and output flow rates in each process in the proposed IUWTE network.

\begin{tabular}{|c|c|c|c|}
\hline WWTP & MEA & MCFC-Rankine cycle & Optimal USN \\
\hline \multicolumn{4}{|c|}{ Input flow rate } \\
\hline $\begin{array}{l}\text { Wastewater: } \\
\text { 233,280 ton/day }\end{array}$ & $\begin{array}{l}\text { Biogas from WWTP: } \\
\text { 29,383 kg/day } \\
\text { Make-up MEA: } \\
\text { 28,996 kg/day } \\
\text { Make-up water: } \\
\text { 666 kg/day }\end{array}$ & $\begin{array}{c}\text { Waste steam from USN: } \\
\mathbf{4 0 , 6 6 2} \mathbf{~ k g} / \text { day } \\
\text { Biomethane from MEA process: } \\
12,036 \mathrm{~kg} / \text { day } \\
\text { Additional fuel: } \\
1,740 \mathrm{~kg} / \text { day }\end{array}$ & $\begin{array}{l}\text { Total fossil fuels: } \\
4,797 \text { ton/day } \\
\text { Water consumption: } \\
\text { 117,504 ton/day }\end{array}$ \\
\hline \multicolumn{4}{|c|}{ Output flow rate } \\
\hline $\begin{array}{c}\text { Biogas: } \\
\text { 29,383 kg/day }\end{array}$ & $\begin{array}{l}\text { Biomethane: } \\
\text { 12,036 kg/day } \\
\text { Captured } \mathrm{CO}_{2} \text { : } \\
4,924 \mathrm{~kg} / \text { day }\end{array}$ & $\begin{array}{c}\text { Emitted } \mathrm{CO}_{2}: \\
1,112 \mathrm{~kg} / \text { day } \\
\text { Produced electricity potential: } \\
\mathbf{4 1 , 3 3 9 ~} \mathbf{k W h} / \text { day }\end{array}$ & $\begin{array}{l}\text { Emitted } \mathrm{CO}_{2}: \\
44 \text { ton/day } \\
\text { Emitted } \mathrm{SO}_{\mathrm{x}} \text { : } \\
51 \text { ton/day } \\
\text { Wasted steam: } \\
\text { 40,662 kg/day }\end{array}$ \\
\hline
\end{tabular}

\subsection{Environmental results from the hybrid GWP pinch analysis}

Hybrid GWP pinch analysis performed in this study can separately clarify the GWPs for each company and cumulative variance of the total GWP in the IUWTE network. Moreover, the specific GWP in the USNs can be demonstrated according to the internal and external factors. The internal factor is subject to the boilers operated in source companies in the USN and a total of 4 boiler types is distributed regarding the types of source companies (Table 4). The external factor is related to the expected GWP amounts in case companies import outside energy sources based on fossil fuels in order to likely meet energy demands and energy requirement in boilers. As aforementioned, $0.68 \mathrm{~kg}$ of $\mathrm{CO}_{2}$ is approximately emitted to generate $1 \mathrm{kWh}$. Table 6 indicates GWP quantities of each company from intenral and external factors in the base case. GWP from the internal factor does not happen in sink companies because they do not operate boilers but gain needed steam from source companies. Source companies in type A whose utility demands are great and in which very high-pressure steam can be harnessed show enormous GWP emissions. GWP from the external factor depends on whether extra electricity is needed from the outside or not. Companies which do not make any GWP based on the external factor use tubines to fulfill energy demands. On the other hand, companies in type $\mathrm{C}$ without self-generation capacity of electricity undoubtedly rely on the external energy sources since they do not encompass any turbines. The total amounts of GWP because of the internal factor are $147,558 \mathrm{~kg}$ of GWP per day and the total quantities of GWP because of the external factor are $9,540 \mathrm{~kg}$ of GWP per day. 
Table 6. The hybrid GWP pinch analysis results of companies in the USN of the base case.

\begin{tabular}{|c|c|c|c|c|c|c|c|c|c|}
\hline & \multicolumn{8}{|c|}{ GWP from internal factor } & \multirow{2}{*}{$\begin{array}{c}\text { GWP from } \\
\text { external factor } \\
\text { Expected } \mathrm{CO}_{2}\end{array}$} \\
\hline & \multicolumn{4}{|c|}{$\mathrm{SO}_{\mathrm{x}}$} & \multicolumn{4}{|c|}{$\mathrm{CO}_{2}$} & \\
\hline \multirow{3}{*}{$\begin{array}{c}\text { Company } \\
\text { S1 }\end{array}$} & & Boil & type & & & Boile & type & & \\
\hline & B1 & $\mathrm{B} 2$ & B3 & B4 & B1 & B2 & B3 & B4 & \\
\hline & & & & & & & & & 748 \\
\hline A1 & 8,976 & 1,055 & & & 6,936 & 1,318 & & & \\
\hline $\mathrm{S} 2$ & & & & & & & & & 1,202 \\
\hline S3 & & & & & & & & & 748 \\
\hline S4 & & & & & & & & & 302 \\
\hline B1 & & & 2,595 & & & & 2,595 & & \\
\hline $\mathrm{C} 1$ & & & & 202 & & & & 202 & 750 \\
\hline S5 & & & & & & & & & 1,504 \\
\hline $\mathrm{C} 2$ & & & & 360 & & & & 360 & 1,054 \\
\hline $\mathrm{A} 2$ & 8,964 & 3,955 & & & & & & & \\
\hline A3 & 18,457 & 2,769 & & & & & & & 466 \\
\hline $\mathrm{C} 3$ & & & & 360 & & & & 360 & 752 \\
\hline B2 & & & 371 & & & & 371 & & 947 \\
\hline A4 & 12,920 & 4,395 & & & 9,984 & 5,493 & & & 1,065 \\
\hline A5 & 7,947 & 4,834 & & & 6,141 & 6,043 & & & \\
\hline Sum & 57,264 & 17,008 & 2,966 & 922 & 44,251 & 21,259 & 2,966 & 922 & 9,540 \\
\hline Total & & 78 & & & & 69 & & & 9,540 \\
\hline
\end{tabular}

Table 7 decribes GWP amounts of each company from the optimized USN based on the developed IUWTE network. Companies that discharge GWP from the internal factor in the optimal USN are the same as those in the existing USN of the base case. Furthermore, source companies of type A also generate much of GWP. The reasons are that both cases are dependent on the same utility demands and maximum steam production capacities for companies and indentical types of boilers are employed in both cases. However, GWP emissions are considerably reduced in the optimized USN. The total $\mathrm{SO}_{\mathrm{x}}$ and $\mathrm{CO}_{2}$ emission amounts in the optimal USN based on the IUWTE network are 50,865 kg per day and 44,174 kg per day, resulting in a decrease of about $35.1 \% \mathrm{SO}_{\mathrm{x}}$ and $36.5 \% \mathrm{CO}_{2}$ compared to the base case. The operation of boilers for steam production to generate electricity via turbines has been optimized by satisfying to some extent energy demands through green electricity from the IUWTE network. GWP generation from the external factor is calculated by distributing expected $\mathrm{CO}_{2}$ amounts in the middle of the construction of the IUWTE network into each company according to the ratios of energy demands. Therefore, companies including great energy demands such as companies A4 or A5 are implied to assign the highest GWP emissions to those companies since significant quantities of green electricity from the IUWTE network are used. Otherwise, in the case of source company B1, any GWP emissions are not assigned to the company B1 because even though boilers in the company B1 were run to generate steam on purpose of the transfer, any energy demands are not required in the company B1. The total sum of GWP emissions from the internal and external factors are $95,039 \mathrm{~kg}$ per day and 6,035 $\mathrm{kg}$ per day, respectively. The results indicate that the GWP emissions from the internal and external factors are decreased by $35.6 \%$ and $36.8 \%$ compared to the base case. 
Table 7. The hybrid GWP pinch analysis results of companies in the optimized USN based on the IUWTE network.

\begin{tabular}{|c|c|c|c|c|c|c|c|c|c|}
\hline & \multicolumn{8}{|c|}{ GWP from internal factor } & \multirow{2}{*}{$\begin{array}{c}\text { GWP from } \\
\text { external factor } \\
\text { Expected } \mathrm{CO}_{2}\end{array}$} \\
\hline & \multicolumn{4}{|c|}{$\mathrm{SO}_{\mathrm{x}}$} & \multicolumn{4}{|c|}{$\mathrm{CO}_{2}$} & \\
\hline & \multicolumn{4}{|c|}{ Boiler type } & \multicolumn{4}{|c|}{ Boiler type } & \\
\hline Company & B1 & $\mathrm{B} 2$ & B3 & B4 & B1 & $\mathrm{B} 2$ & B3 & B4 & \\
\hline S1 & & & & & & & & & 237 \\
\hline A1 & 2,640 & 480 & & & 2,040 & 600 & & & 476 \\
\hline $\mathrm{S} 2$ & & & & & & & & & 476 \\
\hline S3 & & & & & & & & & 237 \\
\hline $\mathrm{S} 4$ & & & & & & & & & 96 \\
\hline B1 & & & 360 & & & & 360 & & \\
\hline $\mathrm{C} 1$ & & & & 202 & & & & 202 & 237 \\
\hline S5 & & & & & & & & & 476 \\
\hline $\mathrm{C} 2$ & & & & 860 & & & & 860 & 333 \\
\hline $\mathrm{A} 2$ & 8,488 & 2,598 & & & 6,559 & 3,248 & & & 570 \\
\hline A3 & 8,488 & 2,769 & & & 6,559 & 3,461 & & & 570 \\
\hline $\mathrm{C} 3$ & & & & 1,248 & & & & 1,248 & 237 \\
\hline B2 & & & 360 & & & & 360 & & 333 \\
\hline A4 & 11,508 & 2,113 & & & 8,892 & 2,641 & & & 950 \\
\hline A5 & 7,947 & 804 & & & 6,141 & 1,004 & & & 809 \\
\hline Sum & 39,071 & 8,764 & 720 & 2,310 & 30,191 & 10,953 & 720 & 2310 & 6,035 \\
\hline Total & & & & & & 44 & & & 6,035 \\
\hline
\end{tabular}

Figure 7 presents the graphical results of the GWP emissions from the internal and external foctors based on the hybrid GWP pinch analysis. The GWP emission amounts of each company because of the internal factor that is the use of boilers are decribed in the Figure 7 (B) and the graph indicates that both of the base case and the optimized case have similar patterns in which source companies of type A discharge most GWP emissions. Figure 7 (C) associated with the GWP emissions from the external factor illustrates that source companies of type $\mathrm{C}$ which do not have any turbines and sink companies enable to directly produce steam have to be supported by the outside energy sources, and the great amounts of GWP emissions are generated. On the other hand, the optimal USN is able to use green electricity from the IUWTE network, and different configuration of the GWP emission pattern has been performed because expected GWP emissions during the implementation of the IUWTE network are distributied alongside the energy demands of each company. Cumulative GWP based on the hybrid GWP pinch analysis incorparting results in Figures 7 (B) and 7 (C) is suggested in Figure 7 (A). Vertical solid lines and inclined dashed lines mean cumulative GWP emissions from the internal and external factor, respectively. The more companies are involoved in the USN, the greater difference between the total GWP emissions occurs. 
(A)

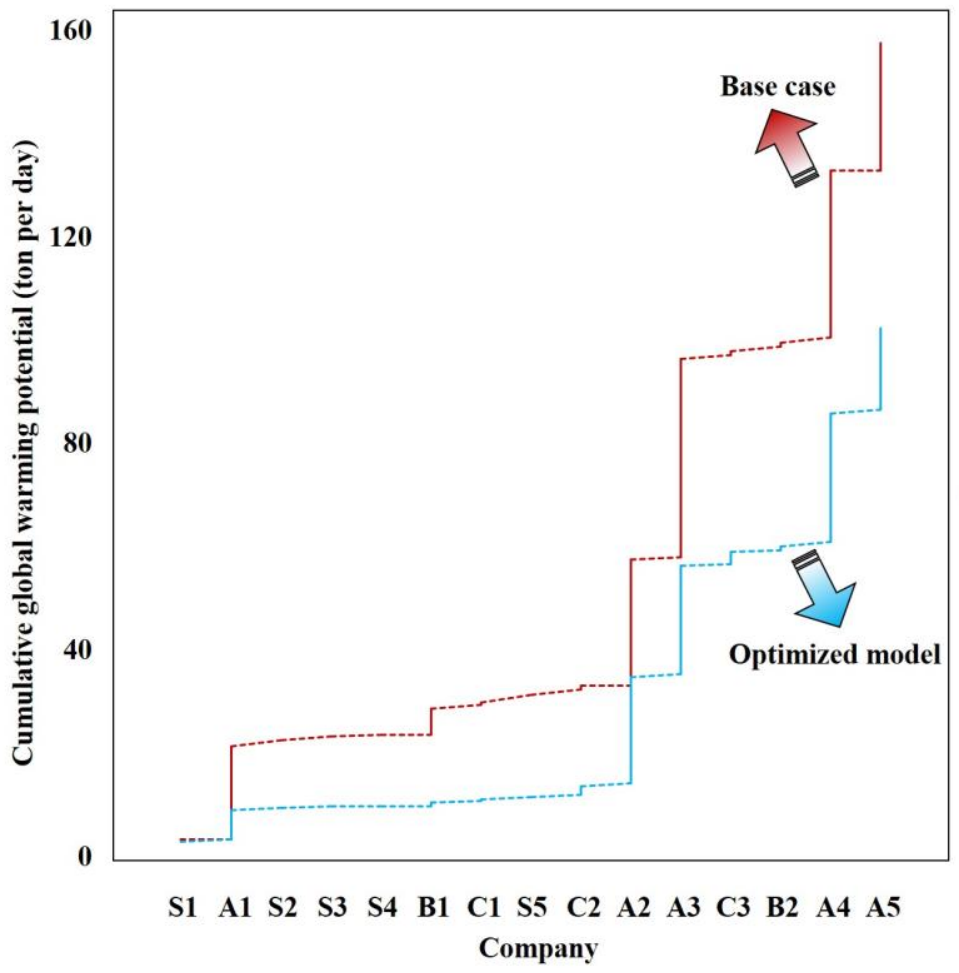

(B)

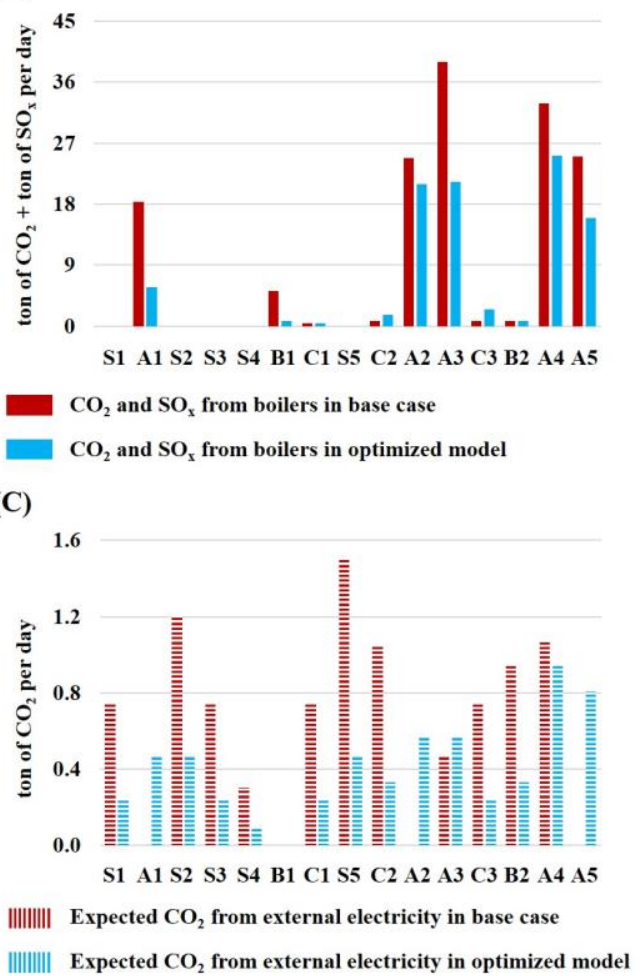

Figure 7. The graphical results from the hybrid GWP pinch analysis in this case study; (A): Cumulative GWP amounts in the base case and the optimized USN from the IUWTE network, (B): GWP quantities of each company from the internal factor, and (C) GWP quantities of each company from the external factor.

The total of 15 companies in the existing USN is considered to optimize the USN based on the IUWTE network. In case more companies in Yeosu petrochemical industrial complex are underpinned by the IUWTE network, the total GWP amounts would be reduced greater than the current optimal results.

As a future perspective, we intended to expand this steady-state analysis of the network with a dynamic systems analysis in which considerations will take into account dynamic changes both in the supply side of waste streams as well as demand side fluctuations. Moreover stochastic based optimization scenarios will also be formulated to assess and propose robust designs and solutions for the waste-to-energy management solutions.

\section{Conclusions}

This study has developed an integrated waste-to-energy system model by integrating the USNs in a huge petrochemical industrial complex with the WTE network starting from the neighboring WWTPs. Biogas produced in WWTPs are used to generate biomethane by using the MEA process as a biogas upgrading process. The upgraded biomethane and thewaste steam from the USNs are utilized in the MCFC system that is combined with Rankine cycle to generate green electricity. The optimization of the existing 
USN is implemented as a mixed integer nonlinear optimization problem where green electricity from the suggested MCFC system is solved to satisfy energy demands in the optimized USN. This research shows significancent findings compared to the existing works as following: First, a huge petrochemical industy and a number of biological processes are integrated to construct advanced WTE network. Second, the developed IUWTE network is described using an integrated model that consist of first-principes/predictive process models describing each subsystems in the network. This allows predictive simulation for the WTE network and the calculation of energy and mass balance as well as utility consumption and production.. As a result, the optimal design of the USN structure has been assessed by considering techno economic objective function. Third, the application of the hybrid GWP pinch analysis using GWP amounts from the IUWTE network indicates detailed GWP emissions and demonstrates the feasibility of the IUWTE from an environemtnal point of view.

The developed model has been applied for a case study of Yeosu petrochemical industrial complex, which has 15 companies in the USN and 16 WWTPs available in the vicinity. Two waste streams, which are wastewater as influent in WWTPs and wasted steam from the USN, have been taken into account. The net green electricity potential from the IUWTE network can properly fulfill energy demands in the optimal USN. The total economic costs of the optimized USN are approximately reduced by $15 \%$ compared to the exisiting USN and according to the developed hybrid GWP pinch analysis, the total GWP emission quantities decrease about $36 \%$ compared to the current USN. The model-based integrated network of this study can be applied for differnet petrochemical industries and if the efficiency of the fuel cell grows according to the technological loadmap, diverse WTE network would be continuously integrated with the results in this study.

\section{Acknowledgement}




\section{Reference}

1. Brunner, P.H. and H. Rechberger, Waste to energy-key element for sustainable waste management. Waste Management, 2015. 37: p. 3-12.

2. Tan, S.T., et al., Energy, economic and environmental (3E) analysis of waste-to-energy (WTE) strategies for municipal solid waste (MSW) management in Malaysia. Energy Conversion and Management, 2015. 102: p. 111-120.

3. Pan, S.-Y., et al., Strategies on implementation of waste-to-energy (WTE) supply chain for circular economy system: a review. Journal of Cleaner Production, 2015. 108: p. 409-421.

4. Balat, M. and M. Balat, Political, economic and environmental impacts of biomass-based hydrogen. International journal of hydrogen energy, 2009. 34(9): p. 3589-3603.

5. Ahammad, S., et al., Source separation increases methane yields for waste-to-energy applications in the personal care product industry. Chemical Engineering Journal, 2014. 244: p. 195-201.

6. Nopens, I., et al., Benchmark Simulation Model No 2: finalisation of plant layout and default control strategy. Water Science and Technology, 2010. 62(9): p. 1967-1974.

7. Shen, Y., et al., An overview of biogas production and utilization at full-scale wastewater treatment plants (WWTPs) in the United States: challenges and opportunities towards energy-neutral WWTPs. Renewable and Sustainable Energy Reviews, 2015. 50: p. 346-362.

8. Lackey, J., P. Champagne, and B. Peppley, Use of wastewater treatment plant biogas for the operation of Solid Oxide Fuel Cells (SOFCs). Journal of environmental management, 2017. 203: p. 753-759.

9. Khan, I.U., et al., Biogas as a renewable energy fuel-A review of biogas upgrading, utilisation and storage. Energy conversion and management, 2017. 150: p. 277-294.

10. Leonzio, G., Upgrading of biogas to bio-methane with chemical absorption process: simulation and environmental impact. Journal of Cleaner Production, 2016. 131: p. 364-375.

11. Franco-Morgado, M., et al., Integral (VOCs, CO2, mercaptans and H2S) photosynthetic biogas upgrading using innovative biogas and digestate supply strategies. Chemical Engineering Journal, 2018. 354: p. 363-369.

12. Hwangbo, S., S. Lee, and C. Yoo, Optimal network design of hydrogen production by integrated utility and biogas supply networks. Applied Energy, 2017. 208: p. 195-209.

13. Nikolaidis, P. and A. Poullikkas, A comparative overview of hydrogen production processes. Renewable and sustainable energy reviews, 2017. 67: p. 597-611.

14. Sharma, S. and S.K. Ghoshal, Hydrogen the future transportation fuel: from production to applications. Renewable and sustainable energy reviews, 2015. 43: p. 1151-1158.

15. Vita, A., C. Italiano, and L. Pino, Distributed H 2 production from bioalcohols and biomethane in conventional steam reforming units, in Bioenergy Systems for the Future. 2017, Elsevier. p. 279320 .

16. Iulianelli, A., F. Dalena, and A. Basile, H 2 production from bioalcohols and biomethane steam reforming in membrane reactors, in Bioenergy Systems for the Future. 2017, Elsevier. p. 321-344.

17. Dodds, P.E., et al., Hydrogen and fuel cell technologies for heating: A review. International journal of hydrogen energy, 2015. 40(5): p. 2065-2083. 
18. Nguyen, V.N., et al., Methane/steam global reforming kinetics over the Ni/YSZ of planar prereformers for SOFC systems. Chemical Engineering Journal, 2016. 292: p. 113-122.

19. Wee, J.-H., Molten carbonate fuel cell and gas turbine hybrid systems as distributed energy resources. Applied Energy, 2011. 88(12): p. 4252-4263.

20. Monteleone, G., et al., Deep H2S removal from biogas for molten carbonate fuel cell (MCFC) systems. Chemical engineering journal, 2011. 173(2): p. 407-414.

21. Mamaghani, A.H., et al., Exergetic, economic, and environmental evaluations and multi-objective optimization of a combined molten carbonate fuel cell-gas turbine system. Applied Thermal Engineering, 2015. 77: p. 1-11.

22. Nami, H., E. Akrami, and F. Ranjbar, Hydrogen production using the waste heat of Benchmark pressurized Molten carbonate fuel cell system via combination of organic Rankine cycle and proton exchange membrane (PEM) electrolysis. Applied Thermal Engineering, 2017. 114: p. 631-638.

23. Boix, M., et al., Optimization methods applied to the design of eco-industrial parks: a literature review. Journal of Cleaner Production, 2015. 87: p. 303-317.

24. Bellantuono, N., N. Carbonara, and P. Pontrandolfo, The organization of eco-industrial parks and their sustainable practices. Journal of Cleaner Production, 2017. 161: p. 362-375.

25. Kim, S.H., et al., Economic and environmental optimization of a multi-site utility network for an industrial complex. Journal of environmental management, 2010. 91(3): p. 690-705.

26. Nagurney, A., J. Dong, and D. Zhang, A supply chain network equilibrium model. Transportation Research Part E: Logistics and Transportation Review, 2002. 38(5): p. 281-303.

27. Hwangbo, S., I.-B. Lee, and J. Han, Multi-period stochastic mathematical model for the optimal design of integrated utility and hydrogen supply network under uncertainty in raw material prices. Energy, 2016. 114: p. 418-430.

28. Hwangbo, S., I.-B. Lee, and J. Han, Mathematical model to optimize design of integrated utility supply network and future global hydrogen supply network under demand uncertainty. Applied Energy, 2017. 195: p. 257-267.

29. Eilering, J.A. and W.J. Vermeulen, Eco-industrial parks: toward industrial symbiosis and utility sharing in practice. Progress in Industrial Ecology, an International Journal, 2004. 1(1-3): p. 245270.

30. Park, H.S. and J.Y. Won, Ulsan eco-industrial park: Challenges and opportunities. Journal of Industrial Ecology, 2007. 11(3): p. 11-13.

31. Chae, S.H., et al., Optimization of a waste heat utilization network in an eco-industrial park. Applied Energy, 2010. 87(6): p. 1978-1988.

32. Avami, A., Assessment of optimal biofuel supply chain planning in Iran: technical, economic, and agricultural perspectives. Renewable and Sustainable Energy Reviews, 2013. 26: p. 761-768.

33. Cambero, C. and T. Sowlati, Assessment and optimization of forest biomass supply chains from economic, social and environmental perspectives $-A$ review of literature. Renewable and Sustainable Energy Reviews, 2014. 36: p. 62-73.

34. Jeppsson, U., et al., Towards a benchmark simulation model for plant-wide control strategy performance evaluation of WWTPs. Water Science and Technology, 2006. 53(1): p. 287-295.

35. Luis, P., Use of monoethanolamine (MEA) for CO2 capture in a global scenario: Consequences and alternatives. Desalination, 2016. 380: p. 93-99.

36. Garcia, M., H.K. Knuutila, and S. Gu, ASPEN PLUS simulation model for CO2 removal with MEA: Validation of desorption model with experimental data. Journal of environmental chemical engineering, 2017. 5(5): p. 4693-4701.

37. Ahn, J., et al., Molten carbonate fuel cell (MCFC)-based hybrid propulsion systems for a liquefied hydrogen tanker. International Journal of Hydrogen Energy, 2018. 43(15): p. 7525-7537.

38. Tan, R.R. and D.C. Foo, Pinch analysis approach to carbon-constrained energy sector planning. Energy, 2007. 32(8): p. 1422-1429. 
39. Atkins, M.J., A.S. Morrison, and M.R. Walmsley, Carbon emissions pinch analysis (CEPA) for emissions reduction in the New Zealand electricity sector. Applied Energy, 2010. 87(3): p. 982987.

40. Freguia, S. and G.T. Rochelle, Modeling of CO2 capture by aqueous monoethanolamine. AIChE Journal, 2003. 49(7): p. 1676-1686.

41. Lee, C.-G., et al., Effect of carbon monoxide addition to the anode of a molten carbonate fuel cell. Journal of power sources, 2004. 125(2): p. 166-171.

42. De Escalona, J.M., et al., A step-by-step methodology to construct a model of performance of molten carbonate fuel cells with internal reforming. international journal of hydrogen energy, 2011. 36(24): p. 15739-15751.

43. Morita, H., et al., Performance analysis of molten carbonate fuel cell using a Li/Na electrolyte. Journal of Power Sources, 2002. 112(2): p. 509-518.

44. Ryan, N.A., et al., Decision Support Algorithm for Evaluating Carbon Dioxide Emissions from Electricity Generation in the United States. Journal of Industrial Ecology, 2018. 22(6): p. 13181330.

45. Rosenthal, R.E., GAMS--a user's guide. 2004. 


\section{Nomenclature}

Sets

$s:$ steam (four types of steam)

$h:$ steam header (four types of steam headers)

$b:$ boiler (four types of boilers)

$c:$ company (source and sink companies)

$f$ : fuel (four types of fossil fuels)

$f t$ : fuel tank (four types of fuel tanks)

$v:$ valve (three types of valve)

$t$ : turbine

$w n$ : water unit

en : electricity unit

Subsets

SOURCE : all source companies

$T A$ : source companies of type A

$T B$ : source companies of type B

$T C$ : source companies of type $\mathrm{C}$

\section{Parameters}

$F I$ : fuel inventory

$B F_{b}$ : boiler efficiency

$C V_{f}$ : calorific value of fuels

$E P_{f}^{S O_{x}}$ : emission parameter of $\mathrm{SO}_{\mathrm{x}}$ 
$E P_{f}^{\mathrm{CO}_{2}}$ : emission parameter of $\mathrm{CO}_{2}$

$F C P_{b}^{E}$ : fixed consumption parameter of electricity in a boiler

$V C P_{b}^{E}$ : variable consumption parameter of electricity in a boiler

$M A X S P_{b, c}:$ maximum steam production

$\operatorname{MINSP}_{b, c}:$ minimum steam production

$B N$ : big number

$S D_{s, c}:$ steam demand

$S C P_{s, s^{\prime}}:$ steam converting parameter

$C P$ : condensate parameter

$T P_{s}:$ turbine parameter for steam

$T P^{\text {Water }}:$ turbine parameter for water

$W D_{c}:$ water demand

$E D_{c}$ : electricity demand

$W 2 E$ : electricity potential from waste-to-energy network

$F P_{f}:$ fuel price

$E C^{S O_{x}}$ : emission charge of $\mathrm{SO}_{x}$

$E C^{\mathrm{CO}_{2}}$ : emission charge of $\mathrm{CO}_{2}$

$W P$ : water price

$E P$ : electricity price

$F C$ : fixed capital parameter

$V C:$ variable capital parameter

$D_{c, c^{\prime}}:$ distance between companies

$O D$ : operating days

$D F:$ depreciation factor

$F O$ : fixed operating parameter

$V O$ : variable operating parameter 
BIOCH 4 : biomethane potential in waste-to-energy network

$S 2 C R$ : steam to carbon ratio

Variables

$X_{f, f t, c}:$ fuel amounts in a fuel tank (ton/day)

$X_{s, b, h, c}:$ steam amounts from a boiler to a steam header in a company (ton/day)

$X_{b, c}^{S O_{x}}: \mathrm{SO}_{\mathrm{x}}$ amounts generated from a boiler (ton/day)

$X_{b, c}^{\mathrm{CO}_{2}}: \mathrm{CO}_{2}$ amounts generated from a boiler (ton/day)

$X_{f, f t, b, c}:$ fuel amounts from a fuel tank to a boiler (ton/day)

$X_{w n, b . c}^{\text {Water }}:$ water amounts from a water unit to a boiler (ton/day)

$X_{e n, b, c}^{E}$ : electricity amounts from a electricity unit to a boiler (kWh/day)

$X_{s, h, c}:$ steam amounts from a steam header to steam demand (ton/day)

$X_{s, h, v, c}$ : steam amounts from a steam header to a valve (ton/day)

$X_{s, v, h, c}:$ steam amounts from a valve to a steam header (ton/day)

$X_{s, h, c, c^{\prime}}$ : steam transfer amounts from a company to another company (ton/day)

$X_{s, h, t, c}:$ steam amounts from a steam header to a turbine (ton/day)

$X_{s, c}^{\text {Waste }}:$ wasted steam amounts (ton/day)

$X_{s, t, h, c}:$ steam amounts from a turbine to a steam header (ton/day)

$X_{t, w n, c}^{\text {Water }}$ : water amounts from a turbine to a water unit (ton/day)

$X_{t, e n, c}^{E}:$ electricity amounts from a turbine to an electricity unit (kWh/day)

$X_{w n, c}^{\text {Water }}:$ water amounts from a water unit to water demand (ton/day)

${ }^{E x} X_{w n, c}^{\text {Water }}$ : water amounts from an external water source to a water unit (ton/day)

${ }^{E x} X_{e n, c}^{E}$ : electricity amounts from an external energy source to an electricity unit (kWh/day)

$X_{e n, c}^{E}$ : electricity amounts from an electricity unit to electricity demand (kWh/day) 
${ }^{M C F C} X_{e n, c}^{E}$ : electricity amounts from MCFC system in waste-to-energy network (kWh/day)

$T R C$ : total raw material costs in a utility supply network (US\$/year)

$T C C$ : total capital costs of a utility supply network (US\$/year)

TOC : total operating costs of a utility supply network (US\$/year)

$T C$ : total costs of a utility supply network (US\$/year)

Binary variable

$B_{s, b, h, c}:$ whether a boiler is operated or not

$B_{s, h, c, c^{\prime}}$ : whether a company is connected with another company or not 